\title{
Essential Oils and Their Constituents Targeting the GABAergic System and Sodium Channels as Treatment of Neurological Diseases
}

\author{
Ze-Jun Wang * and Thomas Heinbockel * (10 \\ Department of Anatomy, Howard University College of Medicine, 520 W Str., NW, Washington, DC 20059, USA \\ * Correspondence: zejunwang@hotmail.com (Z.-J.W.); theinbockel@howard.edu (T.H.); \\ Tel.: +1-202-8069495 (Z.-J.W.); +1-202-8069873 (T.H.)
}

Received: 5 February 2018; Accepted: 27 April 2018; Published: 2 May 2018

\begin{abstract}
Essential oils and the constituents in them exhibit different pharmacological activities, such as antinociceptive, anxiolytic-like, and anticonvulsant effects. They are widely applied as a complementary therapy for people with anxiety, insomnia, convulsion, pain, and cognitive deficit symptoms through inhalation, oral administration, and aromatherapy. Recent studies show that essential oils are emerging as a promising source for modulation of the GABAergic system and sodium ion channels. This review summarizes the recent findings regarding the pharmacological properties of essential oils and compounds from the oils and the mechanisms underlying their effects. Specifically, the review focuses on the essential oils and their constituents targeting the GABAergic system and sodium channels, and their antinociceptive, anxiolytic, and anticonvulsant properties. Some constituents target transient receptor potential (TRP) channels to exert analgesic effects. Some components could interact with multiple therapeutic target proteins, for example, inhibit the function of sodium channels and, at the same time, activate $\mathrm{GABA}_{\mathrm{A}}$ receptors. The review concentrates on perspective compounds that could be better candidates for new drug development in the control of pain and anxiety syndromes.
\end{abstract}

Keywords: essential oils; terpenes; GABA receptor; sodium channel; transient receptor potential (TRP) channel; pain; epilepsy; analgesics; anticonvulsant; anxiolytic; antinociception; CNS; sensory neurons

\section{Introduction}

Essential oils (EOs) are concentrated hydrophobic liquid containing volatile aroma compounds which are extracted from herbs, flowers, and other plant parts. Oil is "essential" in the sense that it contains the "essence of" the plant's fragrance. They are recommended for or encouraged to be applied as a complementary therapy for people with anxiety, pain, bipolar disorder, attention deficit hyperactivity disorder, and depression [1,2]. EOs can be absorbed into the body by oral administration, inhalation, diffusers, baths, and massages. Many studies show that EOs were effective in reducing pain, anxiety, and stress symptoms in animal models and humans with different CNS disorders [1,2]. EO constituents belong mainly to two chemical groups: terpenoids (monoterpenes and sesquiterpenes) and some phenylpropanoid derivatives. Terpenoid group compounds are usually fairly hydrophobic with molecular weights below 300 Daltons [3].

Activation of the $\gamma$-aminobutyric acid (GABA) receptor system and the blockade of neuronal voltage-gated sodium channels $\left(\mathrm{Na}^{+}\right.$channels) are essential for the overall balance between neuronal excitation and inhibition which is vital for normal brain function and critical for the central nervous system (CNS) disorders. It has been suggested that EO constituents could exert their biological 
activities through modulating the GABAergic system and inhibiting $\mathrm{Na}^{+}$channels $[4,5]$. GABA is the major inhibitory neurotransmitter in the CNS and the GABA receptor system exerts a major inhibitory function in the brain. The dysfunction or deficiency of the GABAergic system has been implicated in epilepsy, pain, and anxiety [6]. Neuronal voltage-gated $\mathrm{Na}^{+}$channels mediate the propagation of action potentials along axons, and thus, are thought to be important targets of antiseizure drugs. Local anesthetics and analgesics prevent the transmission of nerve impulses via their binding to $\mathrm{Na}^{+}$ channels. Two main types of $\mathrm{Na}^{+}$currents, termed tetrodotoxin (TTX)-sensitive and TTX-resistant, have been identified in the dorsal root ganglion $[7,8]$. Studies on $\mathrm{Na}^{+}$channels have demonstrated a greater involvement of Nav1.7, a predominant subtype of TTX-sensitive sodium channels expressed principally in peripheral neurons [8], in inflammatory pain $[9,10]$ and in pain sensation $[11,12]$.

Recently, many studies have addressed the potential of natural EOs for treatment of anxiety, convulsion, and pain in humans and in rodents or fish neuropathic models, and the mechanisms underlying the pharmacological profile. The main constituents of EOs were isolated and chemically elucidated. Recent studies indicate that many EOs and their constituents exert pharmacological properties through interactions with the GABAergic system and voltage-gated $\mathrm{Na}^{+}$channels. An increasing number of studies show that: (1) many EOs used for the treatment of anxiety affect the function of the GABAergic system [13-16]; (2) many EOs with antinociceptive and anticonvulsant properties inhibit the function of neuronal voltage-gated $\mathrm{Na}^{+}$channels [17]; (3) some EOs affect the function of both the GABAergic system and voltage-gated $\mathrm{Na}^{+}$channels $[4,18]$.

This review summarizes the beneficial effects of EOs and their constituents targeting the GABAergic system and neuronal voltage-gated $\mathrm{Na}^{+}$channels for $\mathrm{CNS}$ disorders, in particular with respect to their antinociceptive, anticonvulsant, anxiolytic, and sedative effects.

\section{The Pharmacological Activities of EOs and the Underlying Mechanism of Their Actions}

The pharmacological activities of EOs, especially antinociceptive, anticonvulsant, anti-inflammatory, anxiolytic, and sedative effects are summarized in Table 1 which shows the EOs from different plants, their pharmacological activities, and mechanism of actions.

Table 1. The summary of essential oils from different plants, their pharmacological properties, and mechanism of actions.

\begin{tabular}{|c|c|c|c|c|}
\hline $\begin{array}{c}\text { EO Botanical } \\
\text { Origins }\end{array}$ & Administration & Pharmacological Effects & Mechanism of Actions & Authors/Year/Ref. \\
\hline $\begin{array}{c}\text { Achillea Wilhelmsii C. } \\
\text { Koch }\end{array}$ & i.p. & anxiolytic effects & $\begin{array}{l}\text { not probably mediated } \\
\text { through GABA and } \\
\text { opioid receptors }\end{array}$ & Majnooni et al., 2013 [19] \\
\hline $\begin{array}{c}\text { Acorus gramineus } \\
\text { Rhizoma }\end{array}$ & INH; p.o. & $\begin{array}{l}\text { pentylenetetrazole-induced } \\
\text { convulsion; sedative } \\
\text { effect; CNS inhibitory } \\
\text { effects }\end{array}$ & $\begin{array}{c}\text { increased GABA level; } \\
\text { decreased GABA } \\
\text { transaminase }\end{array}$ & Koo et al., 2003 [20] \\
\hline $\begin{array}{l}\text { Acorus tatarinowii } \\
\text { Schott }\end{array}$ & & analgesic effects & inhibited $\mathrm{Na}^{+}$channels & $\begin{array}{l}\text { Moreira-Lobo et al., } \\
2010 \text { [17] }\end{array}$ \\
\hline $\begin{array}{c}\text { Aloysia citrodora } \\
\text { Palau }\end{array}$ & in vitro & $\begin{array}{l}\text { effective antioxidant, } \\
\text { radical-scavenging } \\
\text { activities, and neuronal } \\
\text { protection }\end{array}$ & $\begin{array}{l}\text { inhibited }\left[{ }^{3} \mathrm{H}\right] \text { nicotine } \\
\text { binding }\end{array}$ & $\begin{array}{l}\text { Abuhamdah et al., } \\
2015[21]\end{array}$ \\
\hline Artemisia herba-alba & in vitro & $\begin{array}{l}\text { antifungal and } \\
\text { anti-inflammatory } \\
\text { activities }\end{array}$ & $\mathrm{N} / \mathrm{A}$ & $\begin{array}{l}\text { Abu-Darwish et al., } \\
2015 \text { [22] }\end{array}$ \\
\hline Artemisia ludoviciana & i.p. & antinociceptive activity & $\begin{array}{l}\text { partially mediated by the } \\
\text { opioid system }\end{array}$ & $\begin{array}{c}\text { Anaya-Eugenio et al., } \\
2016 \text { [23] }\end{array}$ \\
\hline Artemisia judaica & in vitro & $\begin{array}{c}\text { antifungal and } \\
\text { anti-inflammatory } \\
\text { activities }\end{array}$ & $\mathrm{N} / \mathrm{A}$ & $\begin{array}{l}\text { Abu-Darwish et al., } \\
2016[24]\end{array}$ \\
\hline
\end{tabular}


Table 1. Cont.

\begin{tabular}{|c|c|c|c|c|}
\hline $\begin{array}{l}\text { EO Botanical } \\
\text { Origins }\end{array}$ & Administration & Pharmacological Effects & Mechanism of Actions & Authors/Year/Ref. \\
\hline Artemisia dracunculus & i.p. & $\begin{array}{l}\text { peripheral and central } \\
\text { antinociceptive activity }\end{array}$ & $\mathrm{N} / \mathrm{A}$ & Maham et al., 2014 [25] \\
\hline $\begin{array}{c}\text { Asarum } \\
\text { heterotropoides }\end{array}$ & INH & $\begin{array}{c}\text { decreased depression-like } \\
\text { behaviors }\end{array}$ & $\mathrm{N} / \mathrm{A}$ & Park et al., 2015 [26] \\
\hline Camellia sinensis & INH & increased sleeping time & $\begin{array}{l}\text { potentiated } \mathrm{GABA}_{\mathrm{A}} \\
\text { receptors }\end{array}$ & Hossain et al., 2004 [27] \\
\hline Citrus aurantium & p.o. & anxiolyticlike activity & $\begin{array}{l}\text { serotonergic system } \\
\left(5-\mathrm{HT} 1_{\mathrm{A}} \text { receptors }\right)\end{array}$ & Costa et al., 2013 [28] \\
\hline Citrus bergamia & & $\begin{array}{l}\text { decreased stress-induced } \\
\text { anxiety }\end{array}$ & $\begin{array}{l}\text { tuning synaptic } \\
\text { plasticity }\end{array}$ & Bagetta et al., 2010 [29] \\
\hline Citrus sinensis & INH & acute anxiolytic activity & $\mathrm{N} / \mathrm{A}$ & Faturi et al., 2010 [30] \\
\hline Coriander & INH & $\begin{array}{c}\text { increased } \\
\text { anxiolytic-antidepressant-like } \\
\text { behaviors, and }\end{array}$ & $\mathrm{N} / \mathrm{A}$ & Cioanca et al., 2014 [31] \\
\hline Cymbopogon citratus & p.o. & anxiolytic-like activity & $\begin{array}{l}\text { potentiated } \mathrm{GABA}_{\mathrm{A}} \\
\text { receptor complex }\end{array}$ & Costa et al., 2011 [13] \\
\hline $\begin{array}{l}\text { Cymbopogon } \\
\text { winterianus Jowitt; } \\
\text { and C. citratus (DC) } \\
\text { Stapf. }\end{array}$ & i.p. & anticonvulsant activities & $\begin{array}{c}\text { via GABAergic } \\
\text { neurotransmission }\end{array}$ & Silva et al., 2010 [32] \\
\hline Dysphania graveolens & p.o. & antinociceptive effects & $\mathrm{N} / \mathrm{A}$ & $\begin{array}{c}\text { Déciga-Campos et al., } \\
2017 \text { [33] }\end{array}$ \\
\hline $\begin{array}{l}\text { Hyptis mutabilis } \\
\text { (Rich.) Briq. }\end{array}$ & p.o. & $\begin{array}{l}\text { sedative and central } \\
\text { anesthetic activities }\end{array}$ & $\begin{array}{l}\text { no involvement of the } \\
\text { GABA }_{A}-B D Z \text { system }\end{array}$ & Silva et al., 2013 [34] \\
\hline Lavandula angustifolia & INH & anxiolytic-like effects & serotonergic system & Chioca et al., 2013 [35] \\
\hline $\begin{array}{c}\text { Lippia alba (Mill.) N.E. } \\
\text { Brown }\end{array}$ & p.o. & central anesthetic effect & $\begin{array}{l}\text { involvement of the } \\
\text { GABAergic system }\end{array}$ & Heldwein et al., 2012 [36] \\
\hline Lemon oil & & $\begin{array}{c}\text { anxiolytic, } \\
\text { antidepressant-like effects }\end{array}$ & $\begin{array}{l}\text { suppression of DA } \\
\text { activity related to } \\
\text { enhanced 5-HTnergic } \\
\text { neurons }\end{array}$ & Komiya et al., 2006 [37] \\
\hline Melissa officinalis & p.o. & $\begin{array}{l}\text { anti-agitation effects in } \\
\text { patients and the } \\
\text { depressant effects in } \\
\text { in-vitro }\end{array}$ & $\begin{array}{l}\text { inhibited GABA-induced } \\
\text { currents }\end{array}$ & $\begin{array}{l}\text { Abuhamdah et al., } \\
\text { 2008 [38] }\end{array}$ \\
\hline $\begin{array}{l}\text { Nigella sativa Seed } \\
\text { lmain components }\end{array}$ & p.o. & $\begin{array}{c}\text { potentiation of } \\
\text { valproate-induced } \\
\text { anticonvulsant effect }\end{array}$ & $\begin{array}{l}\text { increased in GABAergic } \\
\text { response }\end{array}$ & Raza et al., 2008 [39] \\
\hline $\begin{array}{l}\text { Perfume and } \\
\text { phytoncid }\end{array}$ & in vitro & $\begin{array}{l}\text { anxiolytic anticonvulsant } \\
\text { and sedative activity }\end{array}$ & $\begin{array}{l}\text { potentiating } \mathrm{GABA}_{\mathrm{A}} \\
\text { receptors }\end{array}$ & $\begin{array}{c}\text { Aoshima and } \\
\text { Hamamoto, } 1999 \text { [40] }\end{array}$ \\
\hline Piper guineense & INH & $\begin{array}{c}\text { sedative and } \\
\text { anxiolytic-like effects }\end{array}$ & $\mathrm{N} / \mathrm{A}$ & Tankam and Tto, 2013 [2] \\
\hline $\begin{array}{l}\text { Pistacia integerrima } \\
\text { Stewart ex Brandis } \\
\text { Galls }\end{array}$ & in vitro & $\begin{array}{c}\text { relaxant and spasmolytic } \\
\text { effects }\end{array}$ & $\begin{array}{c}\text { involvement of } \\
\beta \text {-adrenoceptors and } \\
\text { calcium channels }\end{array}$ & Shirole et al., 2015 [41] \\
\hline Salvia sclarea & i.p. or $I N H$ & anti-depressant-like effect & $\begin{array}{l}\text { modulating DAnergic } \\
\text { pathway }\end{array}$ & Seol et al., 2010 [42] \\
\hline Syzygium aromaticum & & local anesthesia & $\begin{array}{l}\text { Inhibited sodium } \\
\text { channels }\end{array}$ & Huang et al., 2012 [43] \\
\hline Tagetes minuta $\mathrm{L}$ & $s c$ & anxiogenic-like effects & $\begin{array}{l}\text { negative modulation on } \\
\text { the GABAergic function }\end{array}$ & Marin et al., 1998 [44] \\
\hline $\begin{array}{l}\text { Thymus capitatus } \\
\text { Hoff. et Link. }\end{array}$ & p.o. & antinociceptive activity & $\begin{array}{l}\text { via peripheral nervous } \\
\text { excitability blockade }\end{array}$ & $\begin{array}{l}\text { Gonçalves et al., } \\
2017 \text { [45] }\end{array}$ \\
\hline Valerian officinalis $\mathrm{L}$ & p.o. & sedatives & $\mathrm{N} / \mathrm{A}$ & Houghton, 1999 [46] \\
\hline
\end{tabular}

Note: N/A: not applicable; p.o.: by mouth, oral; sc: subcutaneous injection; i.p.: intraperitoneal injection; INH: inhalation. 


\subsection{EOs with Antinociceptive and Anti-Inflammatory Activities}

EOs that originate from different plants display antinociceptive and anti-inflammatory properties. Bergamot (Citrus bergamia) is a fruit best known for its EO used in aromatherapy to minimize symptoms of stress-induced anxiety and mild mood disorders and cancer pain [29]. The antinociceptive effect of EOs of Salvia sclarea (clary sage), Thymus vulgaris (thyme), and Lavandula angustifolia (true lavender), were examined in the capsaicin test $[29,47]$. The capsaicin test in mice is a reliable model of peripheral nociception, which produces nociceptive behavior similar to that elicited by the intraplantar injection of formalin. Among these EOs, the intraplantar injection of bergamot EO produced a significant antinociceptive effect in mice $[29,47]$.

EOs from the genus Artemisia demonstrated antinociceptive and anti-inflammatory effects. Artemisia dracunculus (tarragon) has been used for the treatment of pain and gastrointestinal disturbances in Iranian traditional medicine [25]. Maham et al. [25] evaluated both central and peripheral antinociceptive activity of tarragon $\mathrm{EO}$ in various experimental models. It was found that the EO possesses a potent antinociceptive effect. Similarly, another EO from Artemisia ludoviciana was also reported to possess antinociceptive activity, which was partially mediated by the opioid system [23]. The aerial parts of Artemisia herba-alba are widely used to treat inflammatory disorders (colds, coughing, bronchitis, diarrhea) are infectious diseases (skin diseases, scabies, syphilis). Recent studies showed that appropriate doses of $A$. herba-alba EO displayed both antifungal and anti-inflammatory activities. Thus, the findings justified and reinforced the use of this plant in traditional medicine [22]. Abu-Darwish et al. [22] characterized the chemical composition of A. herba-alba EO from South Jordan and found that regular monoterpenes were predominant $(39.3 \%)$ and the principal components were $\alpha$ - and $\beta$-thujone (27.7\%). Artemisia judaica L. is a medicinal and aromatic plant growing in the valley bottoms of desert areas. Abu-Darwish et al. [24] studied the chemical composition and biological activities of Artemisia judaica EO. They found that $A$. judaica EO had antifungal and anti-inflammatory activities. For $A$. judaica EO constituents, oxygenated monoterpenes are a representative group of constituents $(68.7 \%)$ in the oil with piperitone $(30.4 \%)$, camphor $(16.1 \%)$, and ethyl cinnamate $(11.0 \%)$ as the main compounds.

Cymbopogon citratus is widely used in traditional medicine as an infusion or decoction, sedative, and analgesic for treating nervous disturbances [13]. An antinociceptive effect of EO from C. citratus has been detected in the rodent hot plate test, an experimental procedure related to central nervous system activity [48].

Dysphania graveolens is a traditional medicinal plant used in Mexico to treat stomach pain. The EO from the aerial parts of $D$. graveolens was recently evaluated in the hot plate and writhing tests in mice [33]. The EO produced an antinociceptive response to thermic and chemical stimuli in a mouse model [33].

\subsection{EOs with Anxiolytic, Anti-Depressive, and Sedative Activities}

Popular anxiolytic oils include those of Anthemis nobilis (chamomile), Salvia sclarea (clary), Rosmarinus officinalis (rosemary), Lavandula angustifolia (lavender), and Rosa damascena (rose) [42]. These EOs have been used medicinally in Europe for thousands of years. In the United States, chamomile is best known as an ingredient in herbal tea preparations advertised as having mild sedation effects. The antidepressant effects of EOs of chamomile (Anthemis nobilis), clary (Salvia sclarea), rosemary (Rosmarinus officinalis), and lavender (Lavandula angustifolia) were assessed using a forced swim test (FST) in rats [42]. It was reported that among the essential oils tested, $5 \%(v / v)$ clary oil had the strongest anti-stressor effect in the FST [42]. The anti-depressive effect of clary oil in vivo could be blocked by dopaminergic antagonists, suggesting the effect is closely associated with the modulation of the dopaminergic (DA) pathway [42].

The fruits, leaves, and roots of Piper guineense have diverse medicinal uses for treating convulsion, rheumatism, and respiratory diseases in African traditional medicine [2]. The inhalation of $P$. guineense EO had significant sedative and anxiolytic effects, suggesting that the EO might 
induce a mild tranquilizing effect. The main compounds of $P$. guineense EO were linalool $(41.8 \%)$ and 3,5-dimethoxytoluene (10.9\%). These two main compounds were shown to play a major role in the sedative activity of $P$. guineense EO [2]. The EO of Piper guineense might exert its sedative effects partially via the GABAergic receptor system [2].

Komiya et al. [37] examined the anti-stress action of the EOs of lavender, rose, and lemon using an elevated plus-maze task, a forced swimming task, and an open field task in mice. Among the tested EOs, lemon oil had the strongest anti-stress effect in all three behavioral tasks. Unfortunately, the authors only indicate that the EOs of lavender, rose, and lemon were supplied by Soda Aromatic Co., Ltd. (Tokyo, Japan), but did not mention the botanical origin of EOs. Despite the fact that rose oil did not show a larger anti-stress effect, it has been reported that rose oil had anti-conflict effects and that the effects were not mediated by the benzodiazepine binding site of the $\mathrm{GABA}_{\mathrm{A}}$ receptor complex [49]. The anxiolytic, antidepressant-like effects of lemon oil were mediated through the suppression of DA activity related to enhanced serotonergic (5-HT) neurons [37]. Lemon oil can be obtained from a species of the Citrus genus [37]. The EO from Citrus aurantium L. was reported to have an anti-stress related effect [28]. Costa et al. (2013) investigated the anxiolytic-like activity of the EO of $C$. aurantium in a light/dark box, and the antidepressant activity in a forced swim test [28]. The acute treatment with the EO showed no activity in the forced swim test, which is sensitive to antidepressants. The studies demonstrated that $C$. aurantium EO exhibited an anxiolytic-like activity which was mediated by 5-HT1A-receptors [28]. The similarity of the mechanism underlying anxiolytic-like activity suggests that lemon oil and EO from C. aurantium may present the same bioactive compounds or analogs which target the serotonergic system. The anxiolytic effects of Citrus sinensis (sweet orange) EO were evaluated on male Wistar rats in the elevated plus-maze followed by the light/dark paradigm [30]. At all doses, C. sinensis oil demonstrated anxiolytic activity in at least one of the tests and, at the highest dose, it presented significant effects in both animal models [30].

Cymbopogon citratus (DC) Stapf., commonly known as lemongrass, and Cymbopogon winterianus Jowitt, are widely used in traditional medicine as an infusion or decoction, sedative, and analgesic for treating nervous disturbances $[13,50]$. The anticonvulsant activities of the EOs from C. winterianus and C. citratus were evaluated in mice [32]. The results showed that both EOs were more active on the pentylenetetrazol-induced convulsion model, and C. citratus was even more efficient in increasing latency to the first convulsion and latency to death. The mechanism of action of the EOs (C. citratus and C. winterianus.) for the anticonvulsant effect was, at least in part, dependent upon GABAergic neurotransmission [32]. Costa et al. [13] investigated the anxiolytic-like activity of $C$. citratus EO in a light/dark box and marble-burying test and the antidepressant activity was investigated in forced-swimming test model in mice. The results demonstrated that acute treatment with the EO from C. citratus was effective against generalized anxiety disorder and epilepsy in experimental procedures in mice [51]. Studies on the underlying mechanism showed that the anxiolytic-like effect of its EO was mediated by the $\mathrm{GABA}_{\mathrm{A}}$ receptor complex [13]. The main EO compounds were identified as monoterpene citral $(71.29 \%)$, a mixture of the stereoisomers geranial and neral, or $\beta$-myrcene $(16.5 \%)[13,52]$.

Asarum heterotropoides was effective in reducing anxiety and inflammation in relief of pain [53-55]. Park et al. (2015) reported that EO of A. heterotropoides effectively attenuated depression-like behavior and increased the brain expression of serotonin $(5-\mathrm{HT})$ in response to six minutes of forced swimming or immobilization stress [26].

The EO of Tugetes minutu L. was found to have anxiogenic-like effects on T-maze and tonic immobility behavior in domestic chicks probably through the negative modulation of GABAergic function [44].

Melissa officinalis is known to have sedative, cognitive-enhancing, and relevant physiological actions. Abuhamdah et al. [38] reported that EO from M. officinalis reversibly inhibited GABA-induced currents in a concentration-dependent manner whereas no inhibition of NMDA- or AMPA-induced currents was noted. Lippia alba (Mill.) N.E. Brown is known as "false-melissa" in Brazil. This plant has 
been commonly used for its sedative properties, which also have been demonstrated in some rodent studies [36,56,57]. Three main chemotypes obtained from L. alba EO were reported and classified according to their major constituent as citral, carvone, and linalool [56]. Recently, the anesthetic effect of L. alba EO was demonstrated in silver catfish and the GABAergic system was involved in this effect [36]. Thus, the EO of L. alba is considered to be a novel natural sedative and anesthetic agent that can be potentially used in aquaculture practices due to its ability to reduce stress in fish with a consequent reduction of economic losses in fish culture [36]. Meanwhile, repeated treatment with an EO from L. alba displayed anxiolytic effects in the elevated T-maze mouse model [58].

Lavender (Lavandula angustifolia) is cultivated worldwide for its EOs, which are used in perfumes, cosmetics, food processing and, more recently, in aromatherapy products. Lavender inhalation has been used in folk medicine for the treatment of anxiety. It was reported that lavender scent reduces the anxiety state in dental patients [59]. Chioca et al. [35] reported that the EO of the plant probably exerted its anxiolytic effect through serotonergic but not GABAergic neurotransmission [35]. Lavender contains linalool and linalyl acetate as its main bioactive components [60,61].

Silva et al. [34] evaluated the sedative and anesthetic properties of Hyptis mutabilis EO and the isolated compounds from EO in silver catfish (Rhamdia quelen). Both the EO and the isolated compounds [(+)-1-terpinen-4-ol and (-)-globulol] showed concentration-dependent sedative and anesthetic effects.

Coriander volatile oil is prepared from Coriander sativum. The oil displays significant anxiolyticand antidepressant-like effects [31]. Moreover, coriander volatile oil decreased the catalase activity and increased glutathione level in the hippocampus [31]. The multiple exposures to coriander volatile oil can be useful as a means to counteract anxiety, depression, and oxidative stress in Alzheimer's disease conditions. The GC-MS and GC-FID analyses determined the main volatile component of the coriander volatile oil sample to be linalool (69.4\%), which is probably the responsible constituent for the observed anxiolytic- and antidepressant-like effects. This assumption was confirmed by the fact that inhaling linalool rich EOs can be useful as a means to counteract anxiety [35,62]. Other minor constituents of coriander volatile oil are $\alpha$-pinene $(3.0 \%-7.0 \%)$ and $\gamma$-terpinene $(1.5-8.0 \%)$ [31].

It was reported that the EO of rhizome and leaf of Acorus gramineus displayed sedative and anticonvulsant properties and also anti-oxidative activity after fragrance inhalation [20]. Koo et al. [20] reported that pre-inhalation of the EO of Acorus gramineus markedly delayed the appearance of pentylenetetrazole-induced convulsion. Moreover, fragrance inhalation progressively prolonged the pentobarbital-induced sleeping time as the inhalation time was lengthened. This sedative effect after inhalation or oral administration of $A$. gramineus EO suggests that this oil may act on the CNS via the GABAergic system. The main components in the EO are $\beta$-asarone (40.3\%), euasarone (17.0\%) and $\alpha$-euasarone (12.3\%) [20].

Valerian (Valerian officinalis L), a common name given to the crude drug consisting of the underground organs of species of the genus Valeriana (Valerianaceae), demonstrated sedative activity [46]. The constituents of the volatile oil of valerian are very variable due to population differences in genetics and environmental factors. The major constituents include the monoterpene bornyl acetate and the sesquiterpene valerenic acid, which is characteristic of the species, in addition to other types of sesquiterpene. The non-volatile monoterpenes known as valepotriates were first isolated in 1966 and contribute to the overall activity by possessing sedative activity based on the effects on the CNS [46]. Valepotriates consist of the furanopyranoid monoterpene skeleton commonly found in the glycosylated forms [46].

EO from Cananga odorata (ylang-ylang EO, YYO) is usually used in reducing blood pressure, improving cognitive functioning in aromatherapy in humans. It was recently reported that YYO displayed anxiolytic effects on anxiety behaviors [63]. YYO and the three main constituents of YYO (benzyl benzoate, linalool, and benzyl alcohol) increased the time that mice visited the open arms and a lightbox area in the elevated plus-maze and light-dark box tests after acute and chronic YYO 
exposures [63]. YYO and its major constituent benzyl benzoate might act on the serotonergic and dopaminergic pathways [63].

A mixture of different EOs was reported to have inhibitory effects on CNS. The central nervous system inhibitory effects of the EO from SuHeXiang Wan (Storax pill) on fragrance inhalation (aromatherapy) were evaluated. SuHeXiang Wan consists of 15 crude herbs, among them Liquidambar orientalis, Saussurea lappa, Aquilaria agallocha, Santalum album, Boswellia carterii, Eugenia caryophyllata, Styrax benzoin, Dryobalanops aromatica, and Cyperus rotundus. All of them have the term "Xiang" (fragrance) in their Chinese plant names. The fragrance inhalation of the EO from SuHeXiang Wan progressively prolonged the pentobarbital-induced sleeping time and inhibited brain lipid peroxidation to which the anticonvulsive action is attributed [15]. The studies confirm that the inhibitory effects of the EO of SuHeXiang Wan on the CNS were mediated by the GABAergic system [15]. Similarly, the perfume, which is a mixture of different EOs, affects the frame of the human mind. The effects of the perfume and phytoncid on $\mathrm{GABA}_{\mathrm{A}}$ receptors expressed in Xenopus oocytes were studied [40]. The chemical constituents in the perfume such as hinokitiol, pinene, eugenol, citronellol, and citronellal potentiated the $\mathrm{GABA}_{\mathrm{A}}$ receptor expressed in Xenopus oocytes. These results suggest that the GABAergic system is a common target of EOs.

In addition to acting on the GABAergic system, the pharmacological effects of EOs may be mediated through other receptor systems. Different species of Achillea are used in folk medicine as sedatives, anti-inflammatory agents, analgesic agents, and anthelmintic (antiparasitic) agents. Majnooni et al. [19] reported that the EO of $A$. wilhelmsii had anxiolytic effects which were probably not mediated through GABA and opioid receptors. Gas chromatography/mass spectrometry (GC/MS) analysis of the EO showed that the main compounds of the oil were $p$-ocimen $(23 \%), 1,8$-cineole $(20.8 \%)$, and carvone (19.13\%). Pistacia integerrima Stewart ex Brandis galls are used in Indian ethnomedicine for their anti-asthmatic, sedative, and spasmolytic properties. The EO of the plant had relaxant and spasmolytic effects which may be mediated by modulating $\beta$-adrenoceptors and calcium channels [41].

\subsection{EOs with Anticonvulsant and Other Pharmacological Properties}

The major chemical components detected in the Aloysia citrodora EOs, derived from dried and fresh leaves, included limonene, geranial, neral, 1,8-cineole, curcumene, spathulenol, and caryophyllene oxide, respectively. A. citrodora leaf EO inhibited $\left[{ }^{3} \mathrm{H}\right]$ nicotine binding to well-washed rat forebrain membranes, and increased iron-chelation in vitro [21]. A. citrodora EO displays the effective antioxidant, radical-scavenging activities, and significant protective properties [21].

Raza et al. [39] investigated the antiepileptic effects of Nigella sativa seed volatile oil and the main components of the oil (that is, thymoquinone, $\alpha$-pinene and $p$-cymene) using pentylenetetrazole (PTZ) and maximal electroshock (MES)-induced convulsions [39]. The volatile oil protected mice effectively against PTZ-induced convulsions that may be attributed mainly to its content of thymoquinone and $p$-cymene and to a lesser extent, $\alpha$-pinene. Volatile oil and its component $p$-cymene effectively suppressed convulsions induced by MES. Their studies suggest that picrotoxin and bicuculline-sensitive GABA receptors mediate an increase in the GABAergic response.

\section{The Pharmacological Properties of Constituents Isolated from EOs and the Underlying Mechanisms of Action}

Natural products have played pivotal roles in neuropharmacology due to their potent and selective targeting of specific biochemical pathways and receptors, and are highly useful as probe substances and therapeutic leads. An increasing amount of evidence shows that EOs present potent bioactive constituents targeting different therapeutic targets $[4,5]$.

Terpenoids and phenylpropanoid derivatives are the main constituents of EOs [3]. The most common terpenoids found in EOs are the monoterpenes and the sesquiterpenes. There is increasing interest in the pharmacological actions of the constituents found in EOs, especially terpenes [3]. Here, we summarize the pharmacological properties of the constituents isolated from EOs and the 
mechanisms underlying their actions. Table 2 is a summary of pharmacological properties of EO constituents from different plants and the underlying mechanisms of their effects.

Table 2. The summary of pharmacological properties of constituents from essential oils of different plants targeting $\mathrm{Na}^{+}$channels and GABAergic system.

\begin{tabular}{|c|c|c|c|}
\hline Constituents & Pharmacological Effects & Mechanism of Actions & Authors/Year/Ref. \\
\hline \multirow[t]{2}{*}{ 1,8-Cineole } & $\begin{array}{l}\text { antinociceptive, smooth } \\
\text { muscle relaxant }\end{array}$ & $\begin{array}{l}\text { reduction of excitability of peripheral } \\
\text { neurons by blocking voltage-dependent } \\
\qquad \mathrm{Na}^{+} \text {current }\end{array}$ & $\begin{array}{l}\text { Ferreira-da-Silva et al., } \\
\qquad 2015[64]\end{array}$ \\
\hline & neuronal excitant & $\begin{array}{l}\text { hyperexcitability and epileptiform } \\
\text { activity in snail neurons by inhibiting } \\
\text { potassium channels }\end{array}$ & $\begin{array}{l}\text { Zeraatpisheh and } \\
\text { Vatanparast, } 2015 \text { [65] }\end{array}$ \\
\hline \multirow[t]{3}{*}{ 1-Nitro-2-phenylethane } & $\begin{array}{l}\text { hypnotic, anti-convulsant and } \\
\text { anxiolytic effects }\end{array}$ & $\mathrm{N} / \mathrm{A}$ & Oyemitan et al., 2013 [66] \\
\hline & $\begin{array}{l}\text { vasorelaxant effects in rat } \\
\text { isolated aortic rings }\end{array}$ & $\begin{array}{l}\text { inhibition of contractile events that are } \\
\text { clearly independent of } \mathrm{Ca}^{2+} \text { influx }\end{array}$ & $\begin{array}{l}\text { Arruda-Barbosa et al., } \\
2014[67]\end{array}$ \\
\hline & vasorelaxant effects & $\mathrm{N} / \mathrm{A}$ & $\begin{array}{l}\text { Interaminense et al., } \\
\qquad 2013[68]\end{array}$ \\
\hline (+)-Borneol & $\begin{array}{c}\text { alleviated mechanical } \\
\text { hyperalgesia in models of } \\
\text { chronic inflammatory and } \\
\text { neuropathic pain }\end{array}$ & $\begin{array}{c}\text { enhanced } \mathrm{GABA}_{\mathrm{A}} \mathrm{R} \text {-mediated } \\
\text { GABAergic transmission }\end{array}$ & JIang et al., 2015 [69] \\
\hline$(+)$ - and (-)-Borneol & analgesia and anesthesia & positive modulation of $\mathrm{GABA}_{\mathrm{A}} \mathrm{R}$ & Granger et al., 2005 [14] \\
\hline (+)-Dehydrofukinone & sedative or anesthetic effects & $\begin{array}{l}\text { interacted with GABAergic receptors; a } \\
\text { suppressor of neuronal excitability }\end{array}$ & Garlet et al., 2016 [70] \\
\hline (S)-Limonene, & Anti-stress effect & via the GABAergic system & Zhou et al., 2009 [71] \\
\hline$(R)-(+)$-Limonene & anxiolytic-like effects & $\mathrm{N} / \mathrm{A}$ & Lima et al., 2013 [72] \\
\hline (+)-Dehydrofukinone & $\begin{array}{l}\text { sedation, anticonvulsant and } \\
\text { anesthesia }\end{array}$ & potentiated $\mathrm{GABA}_{\mathrm{A}}$ receptors & Garlet et al., 2017 [73] \\
\hline \multirow[t]{3}{*}{$\alpha$-asarone } & antiepileptic effect & enhanced tonic GABAergic inhibition & Huang et al., 2013 [54] \\
\hline & antiepileptic effect & $\begin{array}{l}\mathrm{Na}^{+} \text {channel blockade and activation of } \\
\mathrm{GABA}_{\mathrm{A}} \text { receptors }\end{array}$ & Wang ZJ et al., 2014 [4] \\
\hline & anticonvulsant & $\begin{array}{l}\text { blocked } \mathrm{Na}^{+} \text {channel, potentiated } \\
\mathrm{GABA}_{\mathrm{A}} \text { receptors }\end{array}$ & Wang ZJ et al., 2014 [4] \\
\hline$\alpha-(-)-$ Bisabolol & antinociceptive-like effect & $\begin{array}{l}\text { decreased peripheral nerve excitability } \\
\text { probably by blockade of voltage-gated } \\
\qquad \mathrm{Na}^{+} \text {channels }\end{array}$ & Wang YW et al., 2015 [74] \\
\hline$\alpha$-Pinene & anxiolytic and hypnotic effects & $\begin{array}{c}\text { a partial modulator of } \mathrm{GABA}_{\mathrm{A}} \\
\text { receptors and directly binding to the } \\
\text { benzodiazepine binding site of } \mathrm{GABA}_{\mathrm{A}} \\
\text { receptor. }\end{array}$ & Yang et al., 2016 [75] \\
\hline$\beta$-Citronellol & Hypotensive action & $\begin{array}{l}\text { antagonized transmembrane } \mathrm{Ca}^{2+} \\
\text { influx from the extracellular milieu to } \\
\text { produce myorelaxant actions. }\end{array}$ & $\begin{array}{l}\text { Vasconcelos et al., } \\
2016[76]\end{array}$ \\
\hline $\begin{array}{l}(R)-(-) \text {-carvone and } \\
(S)-(+) \text {-carvone }\end{array}$ & antimanic-like effects & $\begin{array}{l}\text { blockade of voltage-gated } \mathrm{Na}^{+} \text {channels; } \\
\text { activating TRPV1 and TRPA1 channels }\end{array}$ & Nogoceke et al., 2016 [77] \\
\hline Benzyl benzoate & anxiolytic effect & $\begin{array}{c}\text { probably through 5-HTnergic and } \\
\text { DAnergic pathways }\end{array}$ & Alves et al., 2016 [63] \\
\hline \multirow[t]{3}{*}{ Carvacrol } & antinematodal action & $\begin{array}{l}\text { nicotinic acetylcholine receptors and } \\
\text { GABA receptors }\end{array}$ & Trailović et al., 2015 [78] \\
\hline & analgesic activity & $\begin{array}{l}\text { reduced excitability of peripheral } \\
\text { neurons; reduced voltage-dependent } \\
\qquad \mathrm{Na}^{+} \text {current }\end{array}$ & $\begin{array}{c}\text { Joca et al., 2012, } 2015 \\
{[79,80]}\end{array}$ \\
\hline & $\begin{array}{l}\text { anxiolytic effects in the } \\
\text { plus-maze test }\end{array}$ & $\begin{array}{l}\text { involvement with GABAergic } \\
\text { transmission }\end{array}$ & Melo et al., 2010 [81] \\
\hline Estragole & $\begin{array}{l}\text { anxiolytic and antimicrobial } \\
\text { activities }\end{array}$ & $\begin{array}{l}\text { inhibition of neuronal excitability by } \\
\text { blocking } \mathrm{Na}^{+} \text {channels }\end{array}$ & $\begin{array}{l}\text { Silva-Alves et al., } \\
2013 \text { [82] }\end{array}$ \\
\hline Eugenol & local analgesic & inhibition of $\mathrm{Na}^{+}$channels & Vatanparast, 2017 [83] \\
\hline
\end{tabular}


Table 2. Cont.

\begin{tabular}{|c|c|c|c|}
\hline Constituents & Pharmacological Effects & Mechanism of Actions & Authors/Year/Ref. \\
\hline & analgesic & $\begin{array}{l}\text { reduced neuronal hyperexcitability by } \\
\text { blocking } \mathrm{Na}^{+} \text {currents }\end{array}$ & Huang et al., 2012 [43] \\
\hline & & inhibition of action potentials & $\begin{array}{l}\text { Moreira-Lobo et al., } \\
2010[17]\end{array}$ \\
\hline Isopulegol & $\begin{array}{l}\text { pentylenetetrazol-induced } \\
\text { convulsions }\end{array}$ & $\begin{array}{l}\text { positive modulation of } \mathrm{GABA}_{\mathrm{A}} \mathrm{R} \text { and } \\
\text { antioxidant properties }\end{array}$ & Silva et al., 2009 [84] \\
\hline Linalool & antinociceptive effect & $\begin{array}{l}\text { blocked excitability by decreasing the } \\
\text { voltage-dependent } \mathrm{Na}^{+} \text {current in } \\
\text { dorsal root ganglion neurons }\end{array}$ & $\begin{array}{l}\text { Leal-Cardoso et al., } \\
\qquad 2010[85]\end{array}$ \\
\hline Menthol & analgesia & $\begin{array}{c}\text { blocked action potentials in frog sciatic } \\
\text { nerves unassociated with TRPM8 } \\
\text { activation }\end{array}$ & Kawasaki et al., 2013 [86] \\
\hline \multirow[t]{3}{*}{ Methyleugenol } & $\begin{array}{l}\text { anticonvulsant, } \\
\text { antinociceptive and anesthetic } \\
\text { activities }\end{array}$ & $\begin{array}{l}\text { agonist of } \mathrm{GABA}_{\mathrm{A}} \text { receptors in cultured } \\
\text { hippocampal neurons }\end{array}$ & Ding et al., 2014 [87] \\
\hline & antinociceptive effect & $\begin{array}{c}\text { inhibition of NMDA receptor-mediated } \\
\text { hyperalgesia via } \mathrm{GABA}_{\mathrm{A}} \text { receptors }\end{array}$ & Yano et al., 2006 [88] \\
\hline & $\begin{array}{l}\text { antinociceptive and anesthetic } \\
\text { actions }\end{array}$ & inhibition of $\mathrm{Na}_{\mathrm{v}} 1.7$ channels & Wang ZJ et al., 2015 [5] \\
\hline Myrtenol and Verbenol & $\begin{array}{l}\text { sedative, anxiolytic and } \\
\text { anticonvulsive effects }\end{array}$ & $\begin{array}{c}\text { augments phasic and tonic GABAergic } \\
\text { inhibition; positive allosteric } \\
\text { modulation of } \mathrm{GABA}_{\mathrm{A}} \text { receptors }\end{array}$ & $\begin{array}{l}\text { van Brederode et al., } \\
2016 \text { [16] }\end{array}$ \\
\hline Nerolidol & $\begin{array}{l}\text { antinociceptive and } \\
\text { anti-inflammatory activity }\end{array}$ & $\begin{array}{l}\text { involvement of the GABAergic system } \\
\text { and proinflammatory cytokines }\end{array}$ & Fonsêca et al., 2016 [89] \\
\hline Terpinen-4-ol & anticonvulsant effects & $\begin{array}{l}\text { involvement of the GABAergic system, } \\
\text { and decrease } \mathrm{Na}^{+} \text {current }\end{array}$ & Nóbrega et al., 2014 [90] \\
\hline Thujone & $\begin{array}{l}\text { muscle spasms and } \\
\text { convulsions }\end{array}$ & GABA receptor antagonist & Mariani et al., 2016 [91] \\
\hline Thymol & antinociception & $\begin{array}{l}\text { nerve conduction inhibition; activated } \\
\text { TRPA1 channels; a positive allosteric } \\
\text { modulator of human } \mathrm{GABA}_{\mathrm{A}} \mathrm{R}\end{array}$ & $\begin{array}{c}\text { Xu et al., } 2015 \text { [92] } \\
\text { Priestley et al., } 2003 \text { [93] }\end{array}$ \\
\hline Thymoquinone & anticonvulsant effects & $\begin{array}{l}\text { opioid receptor-mediated increase in } \\
\text { GABAergic tone }\end{array}$ & $\begin{array}{l}\text { Hosseinzadeh and } \\
\text { Parvardeh, } 2004 \text { [94] }\end{array}$ \\
\hline
\end{tabular}

Note: N/A: not applicable.

\subsection{Analgesic and Anticonvulsant Properties}

The main components of the EOs of aromatic plants, terpenes, and terpenoids are considered important agents in the food industry and for medicinal use. The constituents of the EOs of aromatic plants are emerging therapeutic resources for developing new drugs to treat chronic pain [95]. An increasing number of terpenes and terpenoids are found to have analgesic anti-inflammatory properties.

\subsubsection{Terpenoids with Analgesic Properties Targeting $\mathrm{Na}^{+}$and TRP Channels}

1,8-Cineole is a terpenoid present in many EOs of plants with several pharmacological and biological effects, including antinociceptive, smooth muscle relaxant, and ion channel action. Additionally, 1,8-cineole blocked action potentials, thereby reducing the excitability of peripheral neurons [96,97]. Ferreira-da-Silva et al. [64] demonstrated that 1,8-cineole directly affects $\mathrm{Na}^{+}$channels of the superior cervical ganglion neurons by modifying several gating parameters that are likely to be the major cause of excitability blockade. Eucalyptol reduced the excitability of rat sciatic nerve and superior cervical ganglion neurons [96,97]. On the other hand, Zeraatpisheh and Vatanparast [65] reported that 1,8-cineole (eucalyptol) induced hyperexcitability and epileptiform activity in snail neurons, which is most likely mediated through the direct inhibitory action on the potassium channels.

Menthol (2-isopropyl-5-methylcyclohexanol), which is contained in peppermint or other mint oils, is well-known to induce analgesia by activating the transient receptor potential (TRP) melastatin- 8 
(TRPM8) channels [86]. By recording the compound action potentials (CAPs), Kawasaki et al. [86] examined the effects of menthol and its related compounds on CAP peak amplitude. (-)-Menthol and (+)-menthol concentration-dependently reduced the CAP peak amplitude. (-)-Menthone, $(+)$-menthone, $(-)$-carvone, $(+)$-carvone, $(+)$-carveol, and (+)-pulegone inhibited CAPs with extents similar to that of menthol (see Figure 1) [86]. They found that menthol and its related compounds reduce CAP peak amplitude in a manner specifically related to their chemical structures and that menthol activity is not mediated by TRPM8 channels [86].

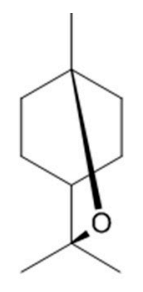

1,8-Cineole<smiles>C=C1CC(C(=C)C)CC=C1C</smiles>

(-)-Carvone<smiles>C=C[C@](C)(O)CCC=C(C)C</smiles>

Linalool<smiles>C=C1C[C@H](C(=C)C)CC=C1C</smiles>

(-)-Carvone<smiles>CC1CC[C@H](C(C)C)C(O)C1</smiles>

(-)-Menthol<smiles>C=C1CC(C(=C)C)CC=C1C</smiles>

(+)-Carvone<smiles>Cc1ccc(C(C)C)cc1O</smiles>

Carvacrol<smiles>C=C1CC(C(=C)C)CC=C1C</smiles>

(+)-Carvone<smiles>CC(C)C1CC[C@@H](C)C[C@H]1O</smiles>

(+)-Menthol

(+)-Menthone<smiles>C=C[C@@](C)(CCC=C(C)C)OC(C)=O</smiles>

(+)-Pulegone Linalyl acetate<smiles>C=CCc1ccc(OC)cc1</smiles>

Estragole<smiles>CC(C)=CCC[C@H](C)[C@H]1CC=C(C)CC1</smiles>

Bisabolol<smiles>CC1=CCC(O)(C(C)C)CC1</smiles>

Terpinen-4-ol

Figure 1. The chemical structures of terpenes with analgesic properties targeting the $\mathrm{Na}^{+}$and transient receptor potential (TRP) channels.

Terpenoids (for example, 1,8-cineole, linalool and linalyl acetate) are the main chemical components of EOs of the Lavandula genus, which includes lavender (Lavandula angustifolia), lavandin (L. angustifolia hybrid L. latifolia), and bergamot (Citrus bergamia). Lavandin is actually a hybrid created from true lavender (L.augustifolia) and spike lavender (L. latifolia). Even though the EO containing linalool and/or linalyl acetate demonstrated an antinociceptive effect [47], the main constituents of the EO, linalool and linalyl acetate (Figure 1), were much more potent than the bergamot EO or other EOs in inhibiting the response to intraplantar capsaicin $[29,47,98]$. Linalool has been the compound mostly 
linked to the anxiolytic effect of lavender [35,60-62,99-101]. Moreover, Takahashi et al. [60] showed that the anxiolytic-like effect of linalool in mice tested in the elevated plus-maze was potentiated by linalyl acetate. Also, it was reported that linalool displayed depressant effects on the central nervous system and olfactory receptors [85]. Leal-Cardoso et al. [85] investigated the effects of linalool on the excitability of peripheral neurons of the somatic sensory system. They found that linalool acts on the somatic sensory system with local anesthetic properties since it blocked the action potential by acting on voltage-dependent $\mathrm{Na}^{+}$channels.

Carvacrol (5-isopropyl-2-methylphenol) (see Figure 1) is a monoterpenic phenol present in the EOs of many plants, especially in the genera Origanum and Thymus [81]. It is the major constituent of the EO fraction of oregano and thyme. Carvacrol has attracted attention because of its beneficial biological activities, especially analgesic activity. Gonçalves et al. [45] characterized the constituents of Thymus capitatus $\mathrm{EO}$ and evaluated their antinociceptive activity by in vivo and in vitro procedures. The EO of T. capitatus presented 33 components, mainly monoterpenes and sesquiterpenes, and carvacrol $(80 \%)$ was its major constituent. EO of T. capitatus dose-dependently decreased the CAP amplitude. Such activity was presumably mediated through voltage-gated $\mathrm{Na}^{+}$channels [45]. Melo et al. [81] examined the behavioral effects of carvacrol using elevated plus-maze (EPM), open field, rotarod, and barbiturate-induced sleeping time tests in mice. The results indicate that carvacrol had anxiolytic effects in the plus-maze test which are not influenced by the locomotor activity in the open-field test [81]. The mechanism underlying the anesthetic and analgesic effects is based on a reduction in neuronal excitability and voltage-gated $\mathrm{Na}^{+}$channel inhibition in peripheral neurons [79]. The hypothesis of the underlying mechanism was supported by the finding that carvacrol could reduce the total voltage-gated $\mathrm{Na}^{+}$current and tetrodotoxin-resistant (TTX-R) $\mathrm{Na}^{+}$current component in a concentration-dependent manner in isolated dorsal root ganglion neurons [80]. In addition to analgesic activity mediated through the blockade of $\mathrm{Na}^{+}$channels [45,80], Trailović et al. [78] tested the effects of different concentrations of carvacrol on isolated tissues of the large pig nematode Ascaris suum. The somatic muscle flaps were used for contraction assays and for electrophysiological investigations. The inhibitory effect of carvacrol on contractions, the inhibition of depolarizations caused by acetylcholine (ACh), and the reduction of conductance changes directly point to an interaction with nicotinic $\mathrm{ACh}$ receptors in A. suum.

Bisabolol, or more formally $\alpha-(-)$-bisabolol or also known as levomenol, is a natural monocyclic sesquiterpene alcohol (Figure 1). It is a primary constituent of the essential oil from Matricaria chamomilla [74]. Bisabolol is known to have anti-irritant, anti-inflammatory, and anti-microbial properties. Recently, it was reported that bisabolol demonstrated an antinociceptive-like effect which could be associated with decreased peripheral nerve excitability [74]. The decreased nervous excitability elicited by $\alpha-(-)$-bisabolol might be caused by an irreversible blockade of voltage-dependent $\mathrm{Na}^{+}$channels [74].

Estragole, a volatile terpenoid, is the primary constituent of EO of tarragon (comprising $60-75 \%$ ). It has several pharmacological and biological activities, including antioxidant, anxiolytic, and antimicrobial activities [82]. The mechanism of action of estragole on neuronal excitability was recently investigated. The intact and dissociated dorsal root ganglion neurons of rats were used to record action potential and $\mathrm{Na}^{+}$currents with intracellular and patch-clamp techniques, respectively. It was found that estragole blocked neuronal excitability by direct inhibition of $\mathrm{Na}^{+}$channel conductance activation.

Carvone ( $p$-mentha-6,8-dien-2-one) (Figure 1) is a chiral monoterpene ketone that is present in Mentha spicata (Spearmint) and Carum carvi (Caraway) EOs and has been shown to have anticonvulsant [102], antinociceptive [103] and anxiolytic-like effects in the elevated T maze [58]. Both $(R)-(-)$-carvone and $(S)-(+)$-carvone decreased peripheral nerve activity, likely through the blockade of voltage-gated $\mathrm{Na}^{+}$channels [77,104]. (S)-(+)-Carvone appears to have anticonvulsant activity against pentylenetetrazole- and picrotoxin-induced seizures [102]. In vivo, both $(R)-(-)$-carvone and (S)-(+)-carvone display antimanic-like effects in two mouse models [77]. 
Kang et al. [105] examined the effects of (-)-carvone and its stereoisomer (+)-carvone (in caraway) on glutamatergic spontaneous excitatory transmission in SG neurons of adult rat spinal cord slices by using the whole-cell patch-clamp technique. They found that (-)-carvone and (+)-carvone activate TRPV1 and TRPA1 channels, respectively, resulting in an increase in spontaneous L-glutamate release onto SG neurons, with almost the same efficacy [105].

Terpinen-4-ol (Figure 1) is a monoterpenoid alcoholic component of EOs obtained from several aromatic plants. Nóbrega et al. [90] investigated the psychopharmacological and electrophysiological activities of Terpinen-4-ol in male Swiss mice and Wistar rats [90]. Terpinen-4-ol (i.p.) inhibited pentylenetetrazol-(PTZ-) induced seizures, indicating anticonvulsant effects. The anticonvulsant action exerted by Terpinen-4-ol involved the GABAergic system but did not bind to the benzodiazepine-binding site of $\mathrm{GABA}_{\mathrm{A}}$ receptors [90]. Furthermore, the electrophysiological results show that terpinen-4-ol decreased a sodium current through voltage-dependent sodium channels [103]. Thus, its anticonvulsant effect may be related to changes in neuronal excitability based on the modulation of both the GABAergic system and $\mathrm{Na}^{+}$channels.

\subsubsection{Terpenes with Analgesic and Anticonvulsant Properties Targeting $\mathrm{GABA}_{\mathrm{A}}$ Receptors}

Hossain et al. [27] electrophysiologically tested the effect of fragrant compounds in oolong tea on $\mathrm{GABA}_{\mathrm{A}}$ receptors which were expressed in Xenopus oocytes. Oolong tea is a traditional Chinese tea that is made by withering the plants with strong sun exposure and oxidation. cis-Jasmone, jasmine lactone, linalool oxide, and methyl jasmonate significantly potentiated the response to GABA. The inhalation of $0.1 \%$ cis-jasmone or methyl jasmonate significantly increased the sleeping time of mice induced by pentobarbital. The results suggest that these fragrant compounds could be absorbed by the brain and thereby potentiated the $\mathrm{GABA}_{\mathrm{A}}$ receptor response to exerting a tranquilizing effect on the brain [27].

Nerolidol is an acyclic sesquiterpene found as a major constituent of several EOs such as Piper claussenianum and Burchardia umbellata [89]. Fonsêca et al. [89] evaluated the antinociceptive activity of nerolidol using the acetic acid-induced writhing test, the formalin test, and the hot-plate test. The results showed that nerolidol had antinociceptive activities in chemical nociception models (acetic acid-induced writhing test and formalin test), but not in the thermal nociception model (hotplate test). The analgesic activity of nerolidol is possibly related to the GABAergic system, and not to the opioidergic system or to ATP-sensitive $\mathrm{K}^{+}$-channels [89].

Natural borneol is (+)-borneol (Figure 2). (+)-Borneol is a bicyclic monoterpene present in the EOs of numerous medicinal plants, including valerian (Valeriana officinalis), chamomile (Matricaria chamomilla), and lavender (Lavandula officinalis). It is used for analgesia and anesthesia in traditional Chinese medicine [69]. (+)-Borneol has remarkable anti-hyperalgesic effects on neuropathic and inflammatory pain in animal models [69]. The results suggest that (+)-borneol may ameliorate mechanical hyperalgesia by enhancing $\mathrm{GABA}_{\mathrm{A}} \mathrm{R}$-mediated GABAergic transmission in the spinal cord and could serve as a therapeutic for chronic pain [69]. Granger et al. [14] reported that both (+)-borneol and its enantiomer (-)-borneol directly potentiate GABA activity at recombinant human $\alpha_{1} \beta_{2} \gamma_{2 L} G A B A_{A}$ receptors are expressed in Xenopus laevis oocytes. Both (+)-borneol and (-)-borneol demonstrated a highly efficacious positive modulating action at $\mathrm{GABA}_{\mathrm{A}}$ receptors [14]. In vivo, (+)-borneol displays significant antinociceptive effect in models of chronic pain in mice without producing a motor deficit. These findings suggest that borneol may ameliorate mechanical hyperalgesia by enhancing $\mathrm{GABA}_{\mathrm{A}} \mathrm{R}$-mediated GABAergic transmission in the spinal cord and could serve as a therapeutic for chronic pain. 


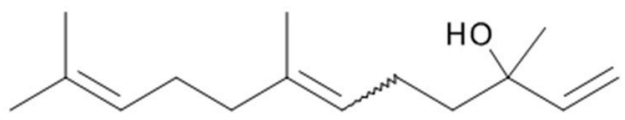

Nerolidol<smiles>Cc1ccc(C(C)C)c(O)c1</smiles>

Thymol

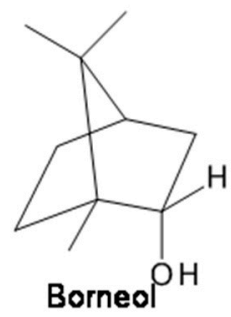<smiles>C=C(C)C1CC[C@@H](C)C[C@H]1O</smiles>

(+)-Isopulegol<smiles>C=C(C)C1CC[C@@H](C)C[C@H]1O</smiles>

(-)-Isopulegol

Figure 2. The chemical structures of terpenes with analgesic and anticonvulsant properties targeting $\mathrm{GABA}_{\mathrm{A}}$ receptors.

Thymol is a monoterpenoid monocyclic phenolic compound. It is the main component of the EO of Thymus vulgaris (Lamiaceae). The main therapeutic application of thymol is in dental preparations to kill odor-producing bacteria and has various actions including antinociception and nerve conduction inhibition $[92,93,106]$. Thymol has been reported to activate transient receptor potential (TRP) channels expressed in heterologous cells [107] and act as a positive allosteric modulator of human GABA $_{A}$ receptors and a homo-oligomeric GABA receptor from Drosophila melanogaster [93]. Thymol displayed inhibition on spontaneous excitatory transmission in adult rat spinal substantia gelatinosa (SG) neurons, suggesting that thymol increases the spontaneous release of L-glutamate onto the neurons by activating TRPA1 channels while producing an outward current without TRP activation [92]. Considering that the substantia gelatinosa plays a pivotal role in modulating nociceptive transmission from the periphery, the actions of thymol could contribute to at least a part of its antinociceptive effect [92].

Isopulegol (p-menth-8-en-3-ol) (Figure 2), a monoterpene alcohol of the menthane family, is present in the EOs of various plants species, such as Eucalyptus citriodora and Zanthoxylum schinifolium [84]. It was found that similar to diazepam, isopulegol significantly prolonged the latency for convulsions and mortality of mice in a PTZ-induced convulsion animal model [84]. The results suggest that the anticonvulsant effects of isopulegol against PTZ-induced convulsions are possibly related to positive modulation of benzodiazepine-sensitive $\mathrm{GABA}_{\mathrm{A}}$ receptors [84].

3.1.3. Phenylpropanoid Derivative Constituents with Analgesic Properties and the Mechanisms of Action

Methyleugenol (4-allyl-1,2-dimethoxybenzene) (Figure 3), a phenylpropanoid derivative, is a natural constituent isolated from EOs of many plants, such as Chinese herb Asari Radix et Rhizoma, having multiple biological effects including anticonvulsant, antinociceptive, and anesthetic activities. The anesthetic property of methyleugenol has been demonstrated by a loss of the righting reflex and decreased sensitivity to a tail pinch in rats and mice, and a loss of the corneal reflex in rabbits [5]. The antinociceptive and anesthetic effects of methyleugenol resulted from the inhibitory action of 
methyleugenol on peripheral $\mathrm{Na}^{+}$channels [5]. Yano et al. [88] tested the effects of methyleugenol on antinociception using the formalin test in mice in vivo. They found that the antinociceptive effect of methyleugenol on the second phase of formalin-induced pain might be due to the inhibition of NMDA receptor-mediated hyperalgesia via $\mathrm{GABA}_{\mathrm{A}}$ receptors. Ding et al. [87] tested the action of methyleugenol on $\mathrm{GABA}_{\mathrm{A}}$ receptors. At lower concentrations $(\sim 30 \mu \mathrm{M})$, methyleugenol significantly potentiated GABA-induced currents in cultured hippocampal neurons [87]. Similarly, methyleugenol potentiated GABA-induced currents mediated by recombinant $\alpha_{1} \beta_{2} \gamma_{2}$ or $\alpha_{5} \beta_{2} \gamma_{2}$ GABA $_{A}$ Rs in human embryonic kidney (HEK) cells. In addition to the blockade of $\mathrm{Na}^{+}$channels [5], this study adds $\mathrm{GABA}_{\mathrm{A}} \mathrm{R}$ activation to the list of molecular targets of methyleugenol [87].

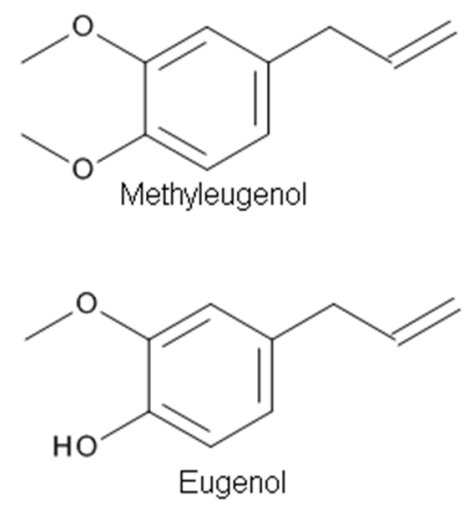

Figure 3. The chemical structures of phenylpropanoid derivatives with analgesic properties.

Eugenol (4-allyl-2-methoxyphenol) (Figure 3), an aromatic phenylpropanoid molecule found in plants including Syzygium aromaticum (Clove), has been used in medicine to relieve pain [43]. The EO of clove, which is made from the aromatic flower buds of a tree in the family Myrtaceae, Syzygium aromaticum, is known as an important weak local anesthetic for dental pain [17,43]. Eugenol possesses analgesic effects that may be related to the inhibition of voltage-dependent $\mathrm{Na}^{+}$channels and/or to the activation of TRPV1 receptors or both. Moreira-Lobo et al. [17] reported that eugenol inhibited action potentials and modified the excitability of the rat sciatic nerve and superior cervical ganglion neurons. Huang et al. [43] reported that eugenol reduced the firing of neuronal action potentials and hyperexcitability through a synergistic blocking effect of $\mathrm{Na}^{+}$currents. Recently, Vatanparast et al. [83] studied the effects of eugenol on the excitability of central neurons of the land snail Caucasotachea atrolabiata and the underlying ionic mechanisms. It was found that a low concentration of eugenol could have antiepileptic properties, while at a higher concentration, it induced epileptiform activity. The dose-dependent inhibition of the ionic currents underlying the rising and falling phases of the action potential seems to be relevant to the eugenol suppressant and excitatory actions, respectively [83].

\subsection{Anxiolytic, Sedative, and Anti-Depressive Properties}

EOs with anxiolytic, anti-depressive, and sedative properties usually interact with the GABAergic system. Some constituents contained in the EOs might act on the GABAergic system to exert their pharmacological effects.

\subsubsection{Terpenes with Anxiolytic and Sedative Properties Targeting the GABAergic System}

An increasing number of terpenes have been reported to have anxiolytic and sedative activities. A promising line of research on terpenes has attributed the sedative and anxiolytic effects to the modulation of $\mathrm{GABA}_{\mathrm{A}}$ receptor function [16].

The monoterpene (+)-limonene (Figure 4), a chemical constituent of various bioactive EOs, is the major chemical component (58.4\%) of the Citrus aurantifolia EO [108]. The anxiolytic-like properties 
of Citrus EOs from C. aurantium L. and sweet orange aroma have been demonstrated in rodent models [30,109]. Bergamot (C. bergamia) is a fruit best known for its EO. The oil is used in aromatherapy to minimize symptoms of stress-induced anxiety and mild mood disorders and cancer pain [29]. The anxiolytic-like effects of (+)-limonene were reported in an elevated maze model of anxiety in mice. However, the molecular target protein of the compound was not studied in that report [72]. s-Limonene is a component of lemon EO. The studies on the anti-stress effect of s-Limonene suggest that the effect may be mediated through the GABAergic system [71].

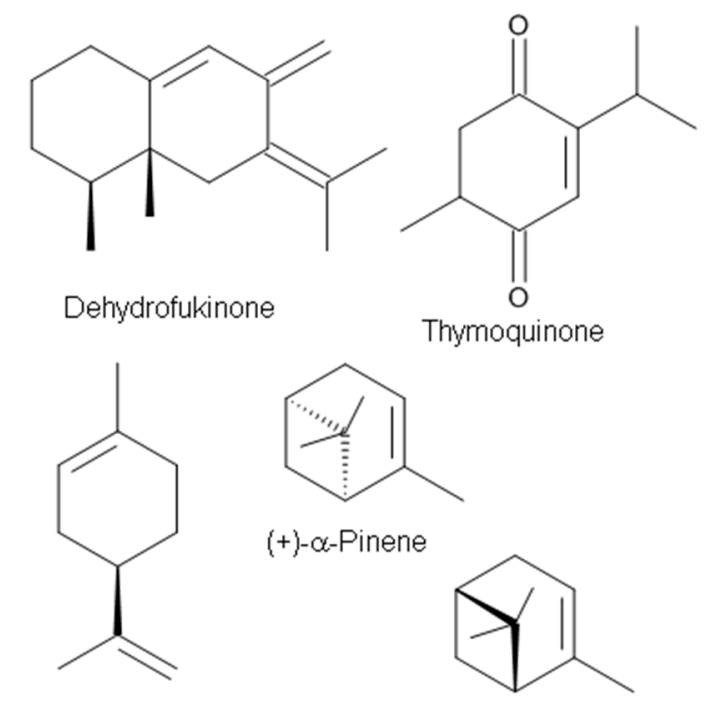

(+)-Limonene

(-)-o-Pinene
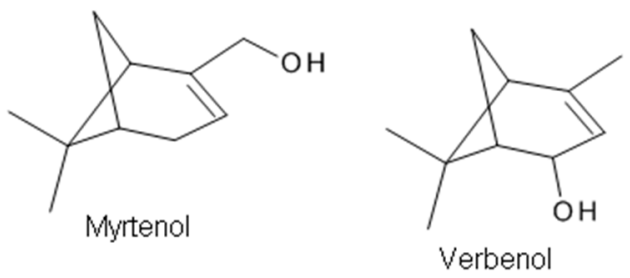

Figure 4. The chemical structures of terpenes with anxiolytic targeting $\mathrm{GABA}_{\mathrm{A}}$ receptors.

(+)-Dehydrofukinone (Figure 4), also known as dihydrokaranone, is an eremophilane-type sesquiterpenoid ketone isolated from Nectandra grandiflora Ness (Lauraceae) EO. Recent behavioral studies have indicated that dehydrofukinone has sedative and anesthetic properties mediated by GABAergic mechanisms in fish [70], and induces sedation and anesthesia by modulation of $\mathrm{GABA}_{\mathrm{A}}$ receptors in a mouse model [73], suggesting that the natural compound (+)-dehydrofukinone has therapeutic potential as a suppressor of neuronal excitability.

Thymoquinone (Figure 4), a major constituent of Nigella sativa seeds EO (27.6-57.0\%), exhibits anticonvulsant activity in the PTZ-induced seizure model [94]. The anticonvulsant effects are probably mediated through an opioid receptor-mediated increase in GABAergic tone. Gilhotra and Dhingra [110] investigated the role of GABAergic and nitriergic modulation in the antianxiety effect of thymoquinone. Thymoquinone $(20 \mathrm{mg} / \mathrm{kg})$ showed anxiolytic effects with a significant decrease in plasma nitrite and the reversal of decreased brain GABA content in stressed mice [110].

Pine EO was reported to have anti-inflammatory, antimicrobial, analgesic, and anti-stress effects [75,111,112]. The main components in the oil are $\alpha$ - and $\beta$-pinene, 3-carene, limonene, and terpinene [113]. $\alpha$-Pinene [2,6,6,-trimethylbicyclo(3.1.1)-2-hept-2-ene] (Figure 3), a major monoterpene of pine EOs, shows anxiolytic and hypnotic effects upon inhaled administration and a sleep enhancing property through a direct binding to $\mathrm{GABA}_{\mathrm{A}}$ receptors by acting as a partial modulator of $\mathrm{GABA}_{\mathrm{A}}$ receptors [75]. 
Sideritis plants and their extracts have been used in traditional medicine as sedatives, anxiolytics, and anticonvulsant agents. Kessler et al. [114] demonstrated that volatile aroma substances in sideritis tea extracts have a powerful modulatory effect on synaptic $\alpha_{1} / \beta_{2} \mathrm{GABA}_{\mathrm{A}}$ Rs (with or without $\gamma_{2}$ subunits) in a heterologous expression system. Pinenes are the most prevalent of the volatile aroma components in Siderites extracts and the pinene metabolites myrtenol and verbenol (Figure 4) have been identified as the most potent positive allosteric modulators of synaptic-type $\mathrm{GABA}_{\mathrm{A}}$ receptors composed of $\alpha_{1} \beta_{2}$ and $\alpha_{1} \beta_{2} \gamma_{2}$ subunits [114]. van Brederode et al. [16] examined the two terpenoids, myrtenol, and verbenol and found augmented tonic GABA currents mediated by extrasynaptic GABA receptors containing the $\delta$ subunit. It was reported that terpenoid substances potentiated the response to GABA in HEK293 cells transfected with $\mathrm{GABA}_{\mathrm{A}}$ Rs composed of subunits that typically mediate tonic GABA inhibition in the brain. Their results suggest that myrtenol and verbenol act as positive allosteric modulators at synaptic and extrasynaptic $\mathrm{GABA}_{\mathrm{A}}$ receptors, thereby augmenting phasic and tonic GABAergic inhibition [16].

\subsubsection{Terpenes with Other Pharmacological Properties}

$\beta$-Citronellol is an alcoholic monoterpene found in EOs such as Cymbopogon citrates, a plant with antihypertensive properties. Vasconcelos et al. [76] assessed its pharmacological effects on the contractility of rat trachea. $\beta$-Citronellol exerted inhibitory effects on rat tracheal rings, with predominant effects on contractions that increased $\mathrm{Ca}^{2+}$ inflow towards the cytosol by voltage-gated pathways [76]. $\beta$-Citronellol antagonized transmembrane $\mathrm{Ca}^{2+}$ influx from the extracellular milieu to produce myorelaxant actions [76].

3.2.3. Non-Terpene Constituents with Anticonvulsant, Anxiolytic Properties, and Their Underlying Mechanisms

$\operatorname{Alpha}(\alpha)$-asarone (Figure 5), a major effective component isolated from the Chinese medicinal herb Acorus tatarinowii, is clinically used as a medication for treating epilepsy, cough, bronchitis, and asthma. Huang et al. [54] evaluated the action of $\alpha$-asarone on the excitability of rat hippocampal neurons in culture and on the epileptic activity induced by pentylenetetrazole or kainite injection in vivo. They found that $\alpha$-asarone inhibits the activity of hippocampal neurons and produces an antiepileptic effect in the central nervous system through enhancing tonic GABAergic inhibition [54]. Using whole-cell patch-clamp recording, $\alpha$-asarone was reported to inhibit the spontaneous firing of output neurons, mitral cells, in a mouse olfactory bulb brain slice preparation [4].

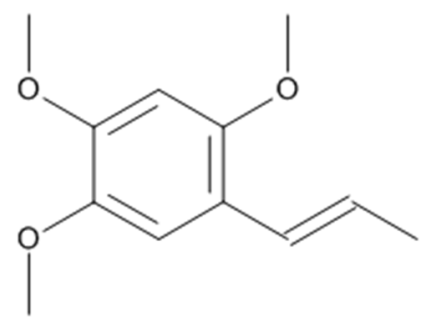

$\alpha$-Asarone

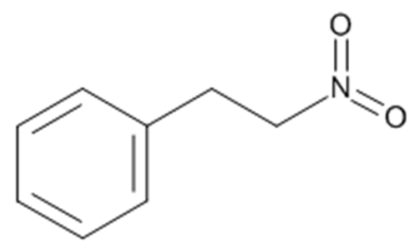

1-Nitro-2-phenylethane

Figure 5. The non-terpene constituents with anticonvulsant and anxiolytic activities. 
It was reported that $\alpha$-asarone alleviates epilepsy by modulating $\mathrm{GABA}_{\mathrm{A}}$ receptors and inhibiting neuronal $\mathrm{Na}^{+}$channels $[4,54]$. While many other compounds like borneol were reported to act as positive allosteric $\mathrm{GABA}_{\mathrm{A}}$ receptor agonists to exert anxiolytic-like effects $[14,16,102]$, recent studies demonstrated that $\alpha$-asarone acted as both a positive allesteric $\mathrm{GABA}_{\mathrm{A}}$ receptor agonist as well as a neuronal $\mathrm{Na}^{+}$channel blocker $[4,5]$.

The compound 1-Nitro-2-phenylethane (Figure 5) is the first nitro compound isolated from plants and is thought to be responsible for the plant's cinnamon scent [67]. It is the main constituent of the EO of Aniba canelilla [67]. The mechanisms underlying the vasorelaxant effects of the EO of Aniba canelilla (EOAC) and its main constituent 1-nitro-2-phenylethane (NP) were investigated in the isolated superior mesenteric artery from spontaneously hypertensive rats (SHRs) [68]. Both EOAC and NP relaxed the contraction evoked by phorbol dibutyrate. Thus, it appears that NP is the active principal component of EOAC $[67,68]$. The vasorelaxation appears to be mediated through the inhibition of contractile events that are independent of $\mathrm{Ca}^{2+}$ influx from the extracellular milieu [67].

The EO of Dennettia tripetala G. Baker (Annonaceae) demonstrated significant analgesic, anti-inflammatory, hypothermic, sedative, muscle relaxant, and central nervous system depressant activities [115]. The EO of $D$. tripetala contains several compounds including 1-nitro-2-phenylethane $(80 \%), \beta$-eudesmol andnerolidol (4\%), 1-linalool (11\%), $\beta$-caryophyllene, and $\beta$-humuline. The compound 1-Nitro-2-phenylethane obtained from the oil of $D$. tripetala exhibited dose-dependent hypnotic, anticonvulsant and anxiolytic effects, and is the compound largely responsible for the neuropharmacological effects of the oil [66].

\subsection{Terpenes with Convulsive Activities Acting as $G A B A_{A}$ Receptor Antagonists}

Most components of EOs act as GABA receptor agonists. Only a few compounds from EOs have been demonstrated to be $\mathrm{GABA}_{\mathrm{A}}$ receptor antagonists. Thujone (Figure 6), a cyclic monoterpenic ketone, is an active ingredient of wormwood oil and some other herbal medicines [91,116]. It is known that thujone is specifically a $\mathrm{GABA}_{\mathrm{A}}$ receptor antagonist and, by inhibiting GABA receptor activation, may make neurons fire more easily, causing muscle spasms and convulsions $[116,117]$. Dihydrocarvone (Figure 6) is present in oils of the caraway plant and is used for its fragrance as flavoring and for medicinal purposes. Dihydrocarvone was recently found to act as a negative allosteric modulator of this receptor [91].
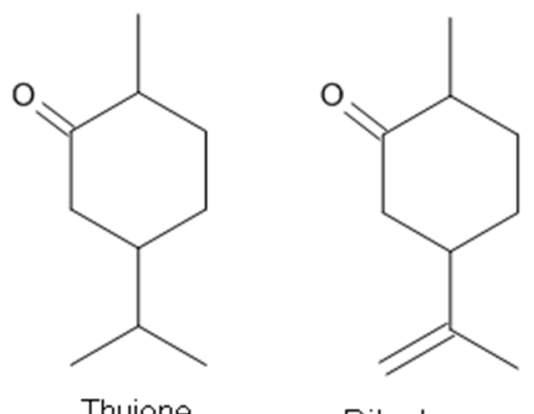

Thujone

Dihydrocarvone

Figure 6. The terpenes acting on $\mathrm{GABA}_{\mathrm{A}}$ receptors as antagonists.

\section{Conclusions}

Based on the findings discussed above, it is clear that natural EOs demonstrate many neuro-pharmacological properties, such as anti-nociceptive, anti-inflammatory, anxiolytic, anti-depressive, and sedative properties. An increasing number of studies show that two inhibitory systems, the GABAergic system and the neuronal voltage-gated $\mathrm{Na}^{+}$channels, are most likely involved in such pharmacological effects. EOs are emerging as a promising source for modulation of the GABAergic system and $\mathrm{Na}^{+}$channels. The neuro-pharmacological activities and the 
underlying mechanisms of many constituents obtained from EOs have been reviewed. Most of the above-mentioned constituents are reported to have either anti-nociceptive or anxiolytic effects through activating the GABAergic system and by inhibiting neuronal $\mathrm{Na}^{+}$channels. Only a few constituents have been reported to antagonize GABA receptors. The perspective compounds targeting the GABAergic system and/or voltage-gated $\mathrm{Na}^{+}$channels could serve as better candidates or pharmacophores during new drug development to control pain and anxiety syndromes.

Author Contributions: Z.-J.W. and T.H. wrote and reviewed the paper.

Acknowledgments: This work was supported by grants from Latham Trust Fund, NIH (MD007597) and NSF (IOS-1355034) to TH.

Conflicts of Interest: The authors declare no conflict of interest.

\section{References}

1. Lee, Y.L.; Wu, Y.; Tsang, H.W.; Leung, A.Y.; Cheung, W.M. A systematic review on the anxiolytic effects of aromatherapy in people with anxiety symptoms. J. Altern. Complement. Med. 2011, 17, 101-108. [CrossRef] [PubMed]

2. Tankam, J.M.; Ito, M. Inhalation of the essential oil of Piper guineense from Cameroon shows sedative and anxiolytic-like effects in mice. Biol. Pharm. Bull. 2013, 36, 1608-1614. [CrossRef] [PubMed]

3. Regnault-Roger, C.; Vincent, C.; Arnason, J.T. Essential oils in insect control: low-risk products in a high-stakes world. Annu. Rev. Entomol. 2012, 57, 405-424. [CrossRef] [PubMed]

4. Wang, Z.J.; Levinson, S.R.; Sun, L.; Heinbockel, T. Identification of both GABAA receptors and voltage-activated $\mathrm{Na}(+)$ channels as molecular targets of anticonvulsant $\alpha$-asarone. Front. Pharmacol. 2014, 5, 40. [CrossRef] [PubMed]

5. Wang, Z.J.; Tabakoff, B.; Levinson, S.R.; Heinbockel, T. Inhibition of Nav1.7 channels by methyl eugenol as a mechanism underlying its antinociceptive and anesthetic actions. Acta. Pharmacol. Sin. 2015, 36, 791-799. [CrossRef] [PubMed]

6. Semyanov, A.; Walker, M.C.; Kullmann, D.M.; Silver, R.A. Tonically active GABA A receptors: Modulating gain and maintaining the tone. Trends Neurosci. 2004, 27, 262-269. [CrossRef] [PubMed]

7. Elliott, A.A.; Elliott, J.R. Characterization of TTX-sensitive and TTX-resistant sodium currents in small cells from adult rat dorsal root ganglia. J. Physiol. 1993, 463, 39-56. [CrossRef] [PubMed]

8. Toledo-Aral, J.J.; Moss, B.L.; He, Z.J.; Koszowski, A.G.; Whisenand, T.; Levinson, S.R.; Wolf, J.J.; Silos-Santiago, I.; Halegoua, S.; Mandel, G. Identification of PN1, a predominant voltage-dependent sodium channel expressed principally in peripheral neurons. Proc. Natl. Acad. Sci. USA 1997, 94, 1527-1532. [CrossRef] [PubMed]

9. Black, J.A.; Liu, S.; Tanak, M.; Cumminsc, T.R.; Waxman, S.G. Changes in the expression of tetrodotoxin-sensitive sodium channels within dorsal root ganglia neurons in inflammatory pain. Pain 2004, 108, 237-247. [CrossRef] [PubMed]

10. Nassar, M.A.; Stirling, L.C.; Forlani, G.; Baker, M.D.; Matthews, E.A.; Dickenson, A.H.; Wood, J.N. Nociceptor-specific gene deletion reveals a major role for Nav1.7 (PN1) in acute and inflammatory pain. Proc. Natl. Acad. Sci. USA 2004, 101, 12706-12711. [CrossRef] [PubMed]

11. Cox, J.J.; Reimann, F.; Nicholas, A.K.; Thornton, G.; Roberts, E.; Springell, K.; Karbani, G.; Jafri, H.; Mannan, J.; Raashid, Y.; et al. An SCN9A channelopathy causes congenital inability to experience pain. Nature 2006, 444, 894-898. [CrossRef] [PubMed]

12. Ahmad, S.; Dahllund, L.; Eriksson, A.B.; Hellgren, D.; Karlsson, U.; Lund, P.E.; Meijer, I.A.; Meury, L.; Mills, T.; Moody, A.; et al. A stop codon mutation in SCN9A causes lack of pain sensation. Hum. Mol. Genet. 2007, 16, 2114-2121. [CrossRef] [PubMed]

13. Costa, C.A.; Kohn, D.O.; de Lima, V.M.; Gargano, A.C.; Flório, J.C.; Costa, M. The GABAergic system contributes to the anxiolytic-like effect of essential oil from Cymbopogon citratus (lemongrass). J. Ethnopharmacol. 2011, 137, 828-836. [CrossRef] [PubMed]

14. Granger, R.E.; Campbell, E.L.; Johnston, G.A. (+)- And (-)-borneol: Efficacious positive modulators of GABA action at human recombinant alpha1beta2gamma2L GABA(A) receptors. Biochem. Pharmacol. 2005, 69, 1101-1111. [CrossRef] [PubMed] 
15. Koo, B.S.; Lee, S.I.; Ha, J.H.; Lee, D.U. Inhibitory effects of the essential oil from SuHeXiang Wan on the central nervous system after inhalation. Biol. Pharm. Bull. 2004, 27, 515-519. [CrossRef] [PubMed]

16. Van Brederode, J.; Atak, S.; Kessler, A.; Pischetsrieder, M.; Villmann, C.; Alzheimer, C. The terpenoids Myrtenol and Verbenol act on $\delta$ subunit-containing GABAA receptors and enhance tonic inhibition in dentate gyrus granule cells. Neurosci. Lett. 2016, 628, 91-97. [CrossRef] [PubMed]

17. Moreira-Lobo, D.C.; Linhares-Siqueira, E.D.; Cruz, G.M.; Cruz, J.S.; Carvalho-de-Souza, J.L.; Lahlou, S.; Coelho-de-Souza, A.N.; Barbosa, R.; Magalhães, P.J.; Leal-Cardoso, J.H. Eugenol modifies the excitability of rat sciatic nerve and superior cervical ganglion neurons. Neurosci. Lett. 2010, 472, 220-224. [CrossRef] [PubMed]

18. Manayi, A.; Nabavi, S.M.; Daglia, M.; Jafari, S. Natural terpenoids as a promising source for modulation of GABAergic system and treatment of neurological diseases. Pharmacol. Rep. 2016, 68, 671-679. [CrossRef] [PubMed]

19. Majnooni, M.B.; Mohammadi-Farani, A.; Gholivand, M.B.; Nikbakht, M.R.; Bahrami, G.R. Chemical composition and anxiolytic evaluation of Achillea Wilhelmsii C. Koch essential oil in rat. Res. Pharm. Sci. 2013, 8, 269-275. [PubMed]

20. Koo, B.S.; Park, K.S.; Ha, J.H.; Park, J.H.; Lim, J.C.; Lee, D.U. Inhibitory effects of the fragrance inhalation of essential oil from Acorus gramineus on central nervous system. Biol. Pharm. Bull. 2003, 26, 978-982. [CrossRef] [PubMed]

21. Abuhamdah, S.; Abuhamdah, R.; Howes, M.J.; Al-Olimat, S.; Ennaceur, A.; Chazot, P.L. Pharmacological and neuroprotective profile of an essential oil derived from leaves of Aloysia citrodora Palau. J. Pharm. Pharmacol. 2015, 67, 1306-1315. [CrossRef] [PubMed]

22. Abu-Darwish, M.S.; Cabral, C.; Gonçalves, M.J.; Cavaleiro, C.; Cruz, M.T.; Efferth, T.; Salgueiro, L. Artemisia herba-alba essential oil from Buseirah (South Jordan): Chemical characterization and assessment of safe antifungal and anti-inflammatory doses. J. Ethnopharmacol. 2015, 174, 153-160. [CrossRef] [PubMed]

23. Anaya-Eugenio, G.D.; Rivero-Cruz, I.; Bye, R.; Linares, E.; Mata, R. Antinociceptive activity of the essential oil from Artemisia ludoviciana. J. Ethnopharmacol. 2016, 179, 403-411. [CrossRef] [PubMed]

24. Abu-Darwish, M.S.; Cabral, C.; Gonçalves, M.J.; Cavaleiro, C.; Cruz, M.T.; Zulfiqar, A.; Khan, I.A.; Efferth, T.; Salgueiro, L. Chemical composition and biological activities of Artemisia judaica essential oil from southern desert of Jordan. J. Ethnopharmacol. 2016, 191, 161-168. [CrossRef] [PubMed]

25. Maham, M.; Moslemzadeh, H.; Jalilzadeh-Amin, G. Antinociceptive effect of the essential oil of tarragon (Artemisia dracunculus). Pharm. Biol. 2014, 52, 208-212. [CrossRef] [PubMed]

26. Park, H.J.; Lim, E.J.; Zhao, R.J.; Oh, S.R.; Jung, J.W.; Ahn, E.M.; Lee, E.S.; Koo, J.S.; Kim, H.Y.; Chang, S.; et al. Effect of the fragrance inhalation of essential oil from Asarum heterotropoides on depression-like behaviors in mice. BMC Complement. Altern. Med. 2015, 15, 43. [CrossRef] [PubMed]

27. Hossain, S.J.; Aoshima, H.; Koda, H.; Kiso, Y. Fragrances in oolong tea that enhance the response of GABAA receptors. Biosci. Biotechnol. Biochem. 2004, 68, 1842-1848. [CrossRef] [PubMed]

28. Costa, C.A.; Cury, T.C.; Cassettari, B.O.; Takahira, R.K.; Flório, J.C.; Costa, M. Citrus aurantium L. essential oil exhibits anxiolytic-like activity mediated by 5 -HT(1A)-receptors and reduces cholesterol after repeated oral treatment. BMC Complement. Altern. Med. 2013, 13, 42. [CrossRef] [PubMed]

29. Bagetta, G.; Morrone, L.A.; Rombolà, L.; Amantea, D.; Russo, R.; Berliocchi, L.; Sakurada, S.; Sakurada, T.; Rotiroti, D.; Corasaniti, M.T. Neuropharmacology of the essential oil of bergamot. Fitoterapia 2010, 81, 453-461. [CrossRef] [PubMed]

30. Faturi, C.B.; Leite, J.R.; Alves, P.B.; Canton, A.C.; Teixeira-Silva, F. Anxiolytic-like effect of sweet orange aroma in Wistar rats. Prog. Neuropsychopharmacol. Biol. Psychiatry 2010, 34, 605-609. [CrossRef] [PubMed]

31. Cioanca, O.; Hritcu, L.; Mihasan, M.; Trifan, A.; Hancianu, M. Inhalation of coriander volatile oil increased anxiolytic-antidepressant-like behaviors and decreased oxidative status in beta-amyloid (1-42) rat model of Alzheimer's disease. Physiol. Behav. 2014, 131, 68-74. [CrossRef] [PubMed]

32. Silva, M.R.; Ximenes, R.M.; da Costa, J.G.; Leal, L.K.; de Lopes, A.A.; Viana, G.S. Comparative anticonvulsant activities of the essential oils (EOs) from Cymbopogon winterianus Jowitt and Cymbopogon citratus (DC) Stapf. in mice. Naunyn. Schmiedebergs. Arch. Pharmacol. 2010, 381, 415-426. [CrossRef] [PubMed]

33. Déciga-Campos, M.; Mata, R.; Rivero-Cruz, I. Antinociceptive pharmacological profile of Dysphania graveolens in mouse. Biomed. Pharmacother. 2017, 89, 933-938. [CrossRef] [PubMed] 
34. Silva, L.L.; Garlet, Q.I.; Benovit, S.C.; Dolci, G.; Mallmann, C.A.; Bürger, M.E.; Baldisserotto, B.; Longhi, S.J.; Heinzmann, B.M. Sedative and anesthetic activities of the essential oils of Hyptis mutabilis (Rich.) Briq. and their isolated components in silver catfish (Rhamdia quelen). Braz. J. Med. Biol. Res. 2013, 46, 771-779. [CrossRef] [PubMed]

35. Chioca, L.R.; Ferro, M.M.; Baretta, I.P.; Oliveira, S.M.; Silva, C.R.; Ferreira, J.; Losso, E.M.; Andreatini, R. Anxiolytic-like effect of lavender essential oil inhalation in mice: Participation of serotonergic but not GABAA/benzodiazepine neurotransmission. J. Ethnopharmacol. 2013, 147, 412-418. [CrossRef] [PubMed]

36. Heldwein, C.G.; Silva, L.L.; Reckziegel, P.; Barros, F.M.; Bürger, M.E.; Baldisserotto, B.; Mallmann, C.A.; Schmidt, D.; Caron, B.O.; Heinzmann, B.M. Participation of the GABAergic system in the anesthetic effect of Lippia alba (Mill.) N.E. Brown essential oil. Braz. J. Med. Biol. Res. 2012, 45, 436-443. [CrossRef] [PubMed]

37. Komiya, M.; Takeuchi, T.; Harada, E. Lemon oil vapor causes an anti-stress effect via modulating the 5-HT and DA activities in mice. Behav. Brain Res. 2006, 172, 240-249. [CrossRef] [PubMed]

38. Abuhamdah, S.; Huang, L.; Elliott, M.S.; Howes, M.J.; Ballard, C.; Holmes, C.; Burns, A.; Perry, E.K.; Francis, P.T.; Lees, G.; et al. Pharmacological profile of an essential oil derived from Melissa officinalis with anti-agitation properties: Focus on ligand-gated channels. J. Pharm. Pharmacol. 2008, 60, 377-384. [CrossRef] [PubMed]

39. Raza, M.; Alghasham, A.A.; Alorainy, M.S.; El-Hadiyah, T.M. Potentiation of Valproate-induced Anticonvulsant Response by Nigella sativa Seed Constituents: The Role of GABA Receptors. Int. J. Health Sci. 2008, 2, 15-25.

40. Aoshima, H.; Hamamoto, K. Potentiation of GABAA receptors expressed in Xenopus oocytes by perfume and phytoncid. Biosci. Biotechnol. Biochem. 1999, 63, 743-748. [CrossRef] [PubMed]

41. Shirole, R.L.; Shirole, N.L.; Saraf, M.N. In vitro relaxant and spasmolytic effects of essential oil of Pistacia integerrima Stewart ex Brandis Galls. J. Ethnopharmacol. 2015, 168, 61-65. [CrossRef] [PubMed]

42. Seol, G.H.; Shim, H.S.; Kim, P.J.; Moon, H.K.; Lee, K.H.; Shim, I.; Suh, S.H.; Min, S.S. Antidepressant-like effect of Salvia sclarea is explained by modulation of dopamine activities in rats. J. Ethnopharmacol. 2010, 130, 187-190. [CrossRef] [PubMed]

43. Huang, C.W.; Chow, J.C.; Tsai, J.J.; Wu, S.N. Characterizing the effects of Eugenol on neuronal ionic currents and hyperexcitability. Psychopharmacology 2012, 221, 575-587. [CrossRef] [PubMed]

44. Marin, R.H.; Garcia, D.A.; Martijena, I.D.; Zygadlo, J.A.; Arce, A.; Perillo, M.A. Anxiogenic-like effects of Tagetes minuta L essential oil on T-maze and tonic immobility behaviour in domestic chicks. Fundam. Clin. Pharmacol. 1998, 12, 426-432. [CrossRef] [PubMed]

45. Gonçalves, J.C.; de Meneses, D.A.; de Vasconcelos, A.P.; Piauilino, C.A.; Almeida, F.R.; Napoli, E.M.; Ruberto, G.; de Araújo, D.A. Essential oil composition and antinociceptive activity of Thymus capitatus. Pharm. Biol. 2017, 55, 782-786. [CrossRef] [PubMed]

46. Houghton, P.J. The scientific basis for the reputed activity of Valerian. J. Pharm. Pharmacol. 1999, 51, 505-512. [CrossRef] [PubMed]

47. Sakurada, T.; Kuwahata, H.; Katsuyama, H.; Katsuyama, S.; Komatsu, T.; Morrone, L.A. Intraplantar injection of bergamot essential oil into the mouse hindpaw: Effects on capsaicin-induced nociceptive behaviors. Int. Rev. Neurobiol. 2009, 85, 235-246.

48. Viana, G.S.B.; Vale, T.G.; Pinho, R.S.N.; Matos, F.J.A. Antinociceptive effect of the essential oil from Cymbopogon citratus in mice. J. Ethnopharmacol. 2000, 70, 323-327. [CrossRef]

49. Umezu, T. Anticonflict effects of plant-derived essential oils. Pharmacol. Biochem. Behav. 1999, 64, 35-40. [CrossRef]

50. Tortoriello, J.; Romero, O. Plants used by Mexican traditional medicine with presumable sedative properties: An ethnobotanical approach. Arch. Med. Res. 1992, 23, 111-116. [PubMed]

51. Blanco, M.M.; Costa, C.A.R.A.; Freire, A.O.; Santos, J.G., Jr.; Costa, M. Neurobehavioral effect of essential oil of Cymbopogon citratus in mice. Phytomedicine 2009, 16, 265-270. [CrossRef] [PubMed]

52. Bidinotto, L.T.; Costa, C.A.; Salvadori, D.M.; Costa, M.; Rodrigues, M.A.; Barbisan, L.F. Protective effects of lemongrass (Cymbopogon citratus STAPF) essential oil on DNA damage and carcinogenesis in female Balb/C mice. J. Appl. Toxicol. 2011, 31, 536-544. [CrossRef] [PubMed]

53. Drew, A.K.; Whyte, I.M.; Bensoussan, A.; Dawson, A.H.; Zhu, X.; Myers, S.P. Chinese herbal medicine toxicology database: Monograph on Herba Asari, "xi xin". J. Toxicol. Clin. Toxicol. 2002, 40, 169-172. [CrossRef] [PubMed] 
54. Huang, C.; Li, W.G.; Zhang, X.B.; Wang, L.; Xu, T.L.; Wu, D.; Li, Y. Alpha-asarone from Acorus gramineus alleviates epilepsy by modulating A-type GABA receptors. Neuropharmacology 2013, 65, 1-11. [CrossRef] [PubMed]

55. Xu, Y.; Cao, C.; Shang, M.; Jiang, Y.; Wang, X.; Li, C.; Ye, J.; Cai, S. Assessment on anti-nociception and anti-inflammation pharmacodynamics of Asarum heterotropoides var. mandshuricum and Asarum sieboldii. Zhongguo Zhong Yao Za Zhi 2012, 37, 625-631. [PubMed]

56. Vale, T.G.; Matos, F.J.; de Lima, T.C.; Viana, G.S. Behavioral effects of essential oils from Lippia alba (Mill.) N.E. Brown chemotypes. J. Ethnopharmacol. 1999, 67, 127-133. [CrossRef]

57. Do Vale, T.G.; Furtado, E.C.; Santos, J.G., Jr.; Viana, G.S. Central effects of citral, myrcene and limonene, constituents of essential oil chemotypes from Lippia alba (Mill.) n.e. Brown. Phytomedicine 2002, 9, 709-714. [CrossRef] [PubMed]

58. Hatano, V.Y.; Torricelli, A.S.; Giassi, A.C.; Coslope, L.A.; Viana, M.B. Anxiolytic effects of repeated treatment with an essential oil from Lippia alba and (R)-(-)-carvone in the elevated T-maze. Braz. J. Med. Biol. Res. 2012, 45, 238-243. [CrossRef] [PubMed]

59. Kritsidima, M.; Newton, T.; Asimakopoulou, K. The effects of lavender scent on dental patient anxiety levels: A cluster randomised-controlled trial. Commun. Dent. Oral. Epidemiol. 2010, 38, 83-87. [CrossRef] [PubMed]

60. Takahashi, M.; Satou, T.; Ohashi, M.; Hayashi, S.; Sadamoto, K.; Koike, K. Interspecies comparison of chemical composition and anxiolytic-like effects of lavender oils upon inhalation. Nat. Prod. Commun. 2011, 6, 1769-1774. [PubMed]

61. Woronuk, G.; Demissie, Z.; Rheault, M.; Mahmoud, S. Biosynthesis and therapeutic properties of Lavandula essential oil constituents. Planta Medica 2011, 77, 7-15. [CrossRef] [PubMed]

62. Linck, V.M.; da Silva, A.L.; Figueiró, M.; Caramão, E.B.; Moreno, P.R.H.; Elisabetsky, E. Effects of inhaled linalool in anxiety, social interaction and aggressive behavior in mice. Phytomedicine 2010, 17, 679-683. [CrossRef] [PubMed]

63. Zhang, N.; Zhang, L.; Feng, L.; Yao, L. The anxiolytic effect of essential oil of Cananga odorata exposure on mice and determination of its major active constituents. Phytomedicine 2016, 23, 1727-1734. [CrossRef] [PubMed]

64. Ferreira-da-Silva, F.W.; da Silva-Alves, K.S.; Alves-Fernandes, T.A.; Coelho-de-Souza, A.N.; Leal-Cardoso, J.H. Effects of 1,8-cineole on $\mathrm{Na}(+)$ currents of dissociated superior cervical ganglia neurons. Neurosci. Lett. 2015, 595, 45-49. [CrossRef] [PubMed]

65. Zeraatpisheh, Z.; Vatanparast, J. Eucalyptol induces hyperexcitability and epileptiform activity in snail neurons by inhibiting potassium channels. Eur. J. Pharmacol. 2015, 764, 70-78. [CrossRef] [PubMed]

66. Oyemitan, I.A.; Elusiyan, C.A.; Akanmu, M.A.; Olugbade, T.A. Hypnotic, anticonvulsant and anxiolytic effects of 1-nitro-2-phenylethane isolated from the essential oil of Dennettia tripetala in mice. Phytomedicine 2013, 20, 1315-1322. [CrossRef] [PubMed]

67. Arruda-Barbosa, L.; Rodrigues, K.M.; Souza-Neto, F.D.; Duarte, G.P.; Borges, R.S.; Magalhães, P.J.; Lahlou, S. Vasorelaxant effects of 1-nitro-2-phenylethene in rat isolated aortic rings. Vasc. Pharmacol. 2014, 63, 55-62. [CrossRef] [PubMed]

68. Interaminense Lde, F.; dos Ramos-Alves, F.E.; de Siqueira, R.J.; Xavier, F.E.; Duarte, G.P.; Magalhães, P.J.; Maia, J.G.; Sousa, P.J.; Lahlou, S. Vasorelaxant effects of 1-nitro-2-phenylethane, the main constituent of the essential oil of Aniba canelilla, in superior mesenteric arteries from spontaneously hypertensive rats. Eur. J. Pharm. Sci. 2013, 48, 709-716. [CrossRef] [PubMed]

69. Jiang, J.; Shen, Y.Y.; Li, J.; Lin, Y.H.; Luo, C.X.; Zhu, D.Y. (+)-Borneol alleviates mechanical hyperalgesia in models of chronic inflammatory and neuropathic pain in mice. Eur. J. Pharmacol. 2015, 757, 53-58. [CrossRef] [PubMed]

70. Garlet, Q.I.; Pires, L.C.; Silva, D.T.; Spall, S.; Gressler, L.T.; Bürger, M.E.; Baldisserotto, B.; Heinzmann, B.M. Effect of (+)-dehydrofukinone on GABAA receptors and stress response in fish model. Braz. J. Med. Biol. Res. 2016, 49, e4872. [CrossRef] [PubMed]

71. Zhou, W.; Yoshioka, M.; Yokogoshi, H. Sub-chronic effects of s-limonene on brain neurotransmitter levels and behavior of rats. J. Nutr. Sci. Vitaminol. 2009, 55, 367-373. [CrossRef] [PubMed] 
72. Lima, N.G.; De Sousa, D.P.; Pimenta, F.C.; Alves, M.F.; De Souza, F.S.; Macedo, R.O.; Cardoso, R.B.; de Morais, L.C.; Melo Diniz Mde, F.; de Almeida, R.N. Anxiolytic-like activity and GC-MS analysis of (R)-(+)-limonene fragrance, a natural compound found in foods and plants. Pharmacol. Biochem. Behav. 2013, 103, 450-454. [CrossRef] [PubMed]

73. Garlet, Q.I.; Pires, L.D.C.; Milanesi, L.H.; Marafiga, J.R.; Baldisserotto, B.; Mello, C.F.; Heinzmann, B.M. (+)-Dehydrofukinone modulates membrane potential and delays seizure onset by GABAa receptor-mediated mechanism in mice. Toxicol. Appl. Pharmacol. 2017, 332, 52-63. [CrossRef] [PubMed]

74. Alves Ade, M.; Gonçalves, J.C.; Cruz, J.S.; Araújo, D.A. Evaluation of the sesquiterpene (-)-alpha-bisabolol as a novel peripheral nervous blocker. Neurosci Lett. 2010, 472, 11-15. [CrossRef] [PubMed]

75. Yang, H.; Woo, J.; Pae, A.N.; Um, M.Y.; Cho, N.C.; Park, K.D.; Yoon, M.; Kim, J.; Lee, C.J.; Cho, S. $\alpha$-Pinene, a major constituent of pine tree oils, enhances non-rapid eye movement sleep in mice through GABAA-benzodiazepine receptors. Mol. Pharmacol. 2016, 90, 530-539. [CrossRef] [PubMed]

76. Vasconcelos, T.B.; Ribeiro-Filho, H.V.; Lucetti, L.T.; Magalhães, P.J. $\beta$-Citronellol, an alcoholic monoterpene with inhibitory properties on the contractility of rat trachea. Braz. J. Med. Biol. Res. 2016, 49, e4800. [CrossRef] [PubMed]

77. Nogoceke, F.P.; Barcaro, I.M.; de Sousa, D.P.; Andreatini, R. Antimanic-like effects of (R)-(-)-carvone and (S)-(+)-carvone in mice. Neurosci. Lett. 2016, 619, 43-48. [CrossRef] [PubMed]

78. Trailović, S.M.; Marjanović, D.S.; Nedeljković Trailović, J.; Robertson, A.P.; Martin, R.J. Interaction of carvacrol with the Ascaris suum nicotinic acetylcholine receptors and gamma-aminobutyric acid receptors, potential mechanism of antinematodal action. Parasitol. Res. 2015, 114, 3059-3068. [CrossRef] [PubMed]

79. Joca, H.C.; Cruz-Mendes, Y.; Oliveira-Abreu, K.; Maia-Joca, R.P.; Barbosa, R.; Lemos, T.L.; Lacerda Beirão, P.S.; Leal-Cardoso, J.H. Carvacrol decreases neuronal excitability by inhibition of voltage-gated sodium channels. J. Nat. Prod. 2012, 75, 1511-1517. [CrossRef] [PubMed]

80. Joca, H.C.; Vieira, D.C.; Vasconcelos, A.P.; Araújo, D.A.; Cruz, J.S. Carvacrol modulates voltage-gated sodium channels kinetics in dorsal root ganglia. Eur. J. Pharmacol. 2015, 756, 22-29. [CrossRef] [PubMed]

81. Melo, F.H.; Venâncio, E.T.; de Sousa, D.P.; de França Fonteles, M.M.; de Vasconcelos, S.M.; Viana, G.S.; de Sousa, F.C. Anxiolytic-like effect of Carvacrol (5-isopropyl-2-methylphenol) in mice: Involvement with GABAergic transmission. Fundam. Clin. Pharmacol. 2010, 24, 437-443. [CrossRef] [PubMed]

82. Silva-Alves, K.S.; Ferreira-da-Silva, F.W.; Peixoto-Neves, D.; Viana-Cardoso, K.V.; Moreira-Júnior, L.; Oquendo, M.B.; Oliveira-Abreu, K.; Albuquerque, A.A.; Coelho-de-Souza, A.N.; Leal-Cardoso, J.H. Estragole blocks neuronal excitability by direct inhibition of Na+ channels. Braz. J. Med. Biol. Res. 2013, 46, 1056-1063. [CrossRef] [PubMed]

83. Vatanparast, J.; Khalili, S.; Naseh, M. Dual effects of eugenol on the neuronal excitability: An in vitro study. Neurotoxicology 2017, 58, 84-91. [CrossRef] [PubMed]

84. Silva, M.I.; Silva, M.A.; de Aquino Neto, M.R.; Moura, B.A.; de Sousa, H.L.; de Lavor, E.P.; de Vasconcelos, P.F.; Macêdo, D.S.; de Sousa, D.P.; Vasconcelos, S.M.; et al. Effects of isopulegol on pentylenetetrazol-induced convulsions in mice: possible involvement of GABAergic system and antioxidant activity. Fitoterapia 2009, 80, 506-513. [CrossRef] [PubMed]

85. Leal-Cardoso, J.H.; da Silva-Alves, K.S.; Ferreira-da-Silva, F.W.; dos Santos-Nascimento, T.; Joca, H.C.; de Macedo, F.H.; de Albuquerque-Neto, P.M.; Magalhães, P.J.; Lahlou, S.; Cruz, J.S.; et al. Linalool blocks excitability in peripheral nerves and voltage-dependent $\mathrm{Na}+$ current in dissociated dorsal root ganglia neurons. Eur. J. Pharmacol. 2010, 645, 86-93. [CrossRef] [PubMed]

86. Kawasaki, H.; Mizuta, K.; Fujita, T.; Kumamoto, E. Inhibition by menthol and its related chemicals of compound action potentials in frog sciatic nerves. Life Sci. 2013, 92, 359-367. [CrossRef] [PubMed]

87. Ding, J.; Huang, C.; Peng, Z.; Xie, Y.; Deng, S.; Nie, Y.Z.; Xu, T.L.; Ge, W.H.; Li, W.G.; Li, F. Electrophysiological characterization of methyleugenol: A novel agonist of GABA(A) receptors. ACS Chem. Neurosci. 2014, 5, 803-811. [CrossRef] [PubMed]

88. Yano, S.; Suzuki, Y.; Yuzurihara, M.; Kase, Y.; Takeda, S.; Watanabe, S.; Aburada, M.; Miyamoto, K. Antinociceptive effect of methyleugenol on formalin-induced hyperalgesia in mice. Eur. J. Pharmacol. 2006, 553, 99-103. [CrossRef] [PubMed] 
89. Fonsêca, D.V.; Salgado, P.R.; de Carvalho, F.L.; Salvadori, M.G.; Penha, A.R.; Leite, F.C.; Borges, C.J.; Piuvezam, M.R.; Pordeus, L.C.; Sousa, D.P.; et al. Nerolidol exhibits antinociceptive and anti-inflammatory activity: Involvement of the GABAergic system and proinflammatory cytokines. Fundam. Clin. Pharmacol. 2016, 30, 14-22. [CrossRef] [PubMed]

90. Nóbrega, F.F.; Salvadori, M.G.; Masson, C.J.; Mello, C.F.; Nascimento, T.S.; Leal-Cardoso, J.H.; de Sousa, D.P.; Almeida, R.N. Monoterpenoid terpinen-4-ol exhibits anticonvulsant activity in behavioural and electrophysiological studies. Oxid. Med. Cell Longev. 2014, 2014. [CrossRef] [PubMed]

91. Mariani, M.E.; Sánchez-Borzone, M.E.; García, D.A. Effects of bioactive monoterpenic ketones on membrane organization. A langmuir film study. Chem. Phys. Lipids 2016, 198, 39-45. [CrossRef] [PubMed]

92. Xu, Z.H.; Wang, C.; Fujita, T.; Jiang, C.Y.; Kumamoto, E. Action of thymol on spontaneous excitatory transmission in adult rat spinal substantia gelatinosa neurons. Neurosci. Lett. 2015, 606, 94-99. [CrossRef] [PubMed]

93. Priestley, C.M.; Williamson, E.M.; Wafford, K.A.; Sattelle, D.B. Thymol, a constituent of thyme essential oil, is a positive allosteric modulator of human $\mathrm{GABA}(\mathrm{A})$ receptors and a homo-oligomeric GABA receptor from Drosophila melanogaster. Br. J. Pharmacol. 2003, 140, 1363-1372. [CrossRef] [PubMed]

94. Hosseinzadeh, H.; Parvardeh, S. Anticonvulsant effects of thymoquinone, the major constituent of Nigella sativa seeds, in mice. Phytomedicine 2004, 11, 56-64. [CrossRef] [PubMed]

95. Guimarães, A.G.; Quintans, J.S.; Quintans, L.J., Jr. Monoterpenes with analgesic activity-a systematic review. Phytother. Res. 2013, 27, 1-15. [CrossRef] [PubMed]

96. Lima-Accioly, P.M.; Lavor-Porto, P.R.; Cavalcante, F.S.; Magalhães, P.J.; Lahlou, S.; Morais, S.M.; Leal-Cardoso, J.H. Essential oil of croton nepetaefolius and its main constituent, 1,8-cineole, block excitability of rat sciatic nerve in vitro. Clin. Exp. Pharmacol. Physiol. 2006, 33, 1158-1163. [CrossRef] [PubMed]

97. Ferreira-da-Silva, F.W.; Barbosa, R.; Moreira-Júnior, L.; dos Santos-Nascimento, T.; de Oliveira-Martins, M.D.; Coelho-de-Souza, A.N.; Cavalcante, F.S.; Ceccatto, V.M.; de Lemos, T.L.; Magalhães, P.J.; et al. Effects of 1,8-cineole on electrophysiological parameters of neurons of the rat superior cervical ganglion. Clin. Exp. Pharmacol. Physiol. 2009, 36, 1068-1073. [CrossRef] [PubMed]

98. Lesage-Meessen, L.; Bou, M.; Sigoillot, J.C.; Faulds, C.B.; Lomascolo, A. Essential oils and distilled straws of lavender and lavandin: A review of current use and potential application in white biotechnology. Appl. Microbiol. Biotechnol. 2015, 99, 3375-3385. [CrossRef] [PubMed]

99. Linck, V.M.; da Silva, A.L.; Figueiró, M.; Piato, A.L.; Herrmann, A.P.; Dupont Birck, F.; Caramão, E.B.; Nunes, D.S.; Moreno, P.R.; Elisabetsky, E. Inhaled linalool induced sedation in mice. Phytomedicine 2009, 16, 303-307. [CrossRef] [PubMed]

100. Tsang, H.W.; Ho, T.Y. A systematic review on the anxiolytic effects of aromatherapy on rodents under experimentally induced anxiety models. Rev. Neurosci. 2010, 21, 141-152. [CrossRef] [PubMed]

101. Umezu, T.; Nagano, K.; Ito, H.; Kosakai, K.; Sakaniwa, M.; Morita, M. Anticonflict effects of lavender oil and identification of its active constituents. Pharmacol. Biochem. Behav. 2006, 85, 713-721. [CrossRef] [PubMed]

102. de Sousa, D.P.; de Farias Nóbrega, F.F.; de Almeida, R.N. Influence of the chirality of $(R)-(-)-$ and (S)-(+)-carvone in the central nervous system: A comparative study. Chirality 2007, 19, 264-268. [CrossRef] [PubMed]

103. Gonçalves, J.C.; Oliveira Fde, S.; Benedito, R.B.; de Sousa, D.P.; de Almeida, R.N.; de Araújo, D.A. Antinociceptive activity of (-)-carvone: Evidence of association with decreased peripheral nerve excitability. Biol. Pharm. Bull. 2008, 31, 1017-1020. [CrossRef] [PubMed]

104. Gonçalves, J.C.; Alves Ade, M.; de Araújo, A.E.; Cruz, J.S.; Araújo, D.A. Distinct effects of carvone analogues on the isolated nerve of rats. Eur. J. Pharmacol. 2010, 645, 108-112. [CrossRef] [PubMed]

105. Kang, Q.; Jiang, C.Y.; Fujita, T.; Kumamoto, E. Spontaneous L-glutamate release enhancement in rat substantia gelatinosa neurons by (-)-carvone and (+)-carvone which activate different types of TRP channel. Biochem. Biophys. Res. Commun. 2015, 459, 498-503. [CrossRef] [PubMed]

106. Angeles-López, G.; Pérez-Vásquez, A.; Hernández-Luis, F.; Déciga-Campos, M.; Bye, R.; Linares, E.; Mata, R. Antinociceptive effect of extracts and compounds from Hofmeisteria schaffneri. J. Ethnopharmacol. 2010, 131, 425-432. [CrossRef] [PubMed]

107. Xu, H.; Delling, M.; Jun, J.C.; Clapham, D.E. Oregano, thyme and clove-derived flavors and skin sensitizers activate specific TRP channels. Nat. Neurosci. 2006, 9, 628-635. [CrossRef] [PubMed] 
108. Spadaro, F.; Costa, R.; Circosta, C.; Occhiuto, F. Volatile composition and biological activity of key lime Citrus aurantifolia essential oil. Nat. Prod. Commun. 2012, 7, 1523-1526. [PubMed]

109. Pultrini Ade, M.; Galindo, L.A.; Costa, M. Effects of the essential oil from Citrus aurantium L. in experimental anxiety models in mice. Life Sci. 2006, 78, 1720-1725. [CrossRef] [PubMed]

110. Gilhotra, N.; Dhingra, D. Thymoquinone produced antianxiety-like effects in mice through modulation of GABA and NO levels. Pharmacol. Rep. 2011, 63, 660-669. [CrossRef]

111. Süntar, I.; Tumen, I.; Ustün, O.; Keles, H.; Akkol, E.K. Appraisal on the wound healing and anti-inflammatory activities of the essential oils obtained from the cones and needles of Pinus species by in vivo and in vitro experimental models. J. Ethnopharmacol. 2012, 139, 533-540. [CrossRef] [PubMed]

112. Xie, Q.; Liu, Z.; Li, Z. Chemical composition and antioxidant activity of essential oil of six pinus taxa native to China. Molecules 2015, 20, 9380-9392. [CrossRef] [PubMed]

113. Judzentiene, A.; Kupcinskiene, E. Chemical composition on essential oils from needles of Pinus sylvestris L. grown in northern Lithuania. J. Essent. Oil Res. 2008, 20, 26-29. [CrossRef]

114. Kessler, A.; Sahin-Nadeem, H.; Lummis, S.C.; Weigel, I.; Pischetsrieder, M.; Buettner, A.; Villmann, C. GABA(A) receptor modulation by terpenoids from Sideritis extracts. Mol. Nutr. Food Res. 2014, 58, 851-862. [CrossRef] [PubMed]

115. Oyemitan, I.A.; Iwalewa, E.O.; Akanmu, M.A.; Olugbade, T.A. Antinociceptive and antiinflammatory effects of essential oil of Dennettia tripetala G. Baker (Annonaceae) in rodents. Afr. J. Tradit. Complement. Altern. Med. 2008, 5, 355-362. [CrossRef] [PubMed]

116. Höld, K.M.; Sirisoma, N.S.; Ikeda, T.; Narahashi, T.; Casida, J.E. Alpha-thujone (the active component of absinthe): Gamma-aminobutyric acid type a receptor modulation and metabolic detoxification. Proc. Natl. Acad. Sci USA 2000, 97, 3826-3831. [CrossRef] [PubMed]

117. Reiner, G.N.; Delgado-Marín, L.; Olguín, N.; Sánchez-Redondo, S.; Sánchez-Borzone, M.; Rodríguez-Farré, E.; Suñol, C.; García, D.A. GABAergic pharmacological activity of propofol related compounds as possible enhancers of general anesthetics and interaction with membranes. Cell Biochem. Biophys. 2013, 67, 515-525. [CrossRef] [PubMed] 